\&EPA

\title{
Compendium of
}

ORD and OSWER

Documents Relevant

to RCRA Corrective

Action 


\section{DISCLAIMER}

This report was prepared as an account of work sponsored by an agency of the United States Government. Neither the United States Government nor any agency thereof, nor any of their employees, make any warranty, express or implied, or assumes any legal liability or responsibility for the accuracy, completeness, or usefulness of any information, apparatus, product, or process disclosed, or represents that its use would not infringe privately owned rights. Reference herein to any specific commercial product, process, or service by trade name, trademark, manufacturer, or otherwise does not necessarily constitute or imply its endorsement, recommendation, or favoring by the United States Government or any agency thereof. The views and opinions of authors expressed herein do not necessarily state or reflect those of the United States Government or any agency thereof. 


\section{DISCLAIMER}

Portions of this document may be illegible in electronic image products. Images are produced from the best available original document. 


\section{Compendium of}

\section{ORD and OSWER Documents}

\section{Relevant to RCRA Corrective Action}

U.S. Environmental Protection Agency

Office of Solld Waste

Permits and State Programs Division

March 1992

MASTER 


\section{Preface}

This document was prepared by NUS Corporation, Gaithersburg, Maryland, and updated by LABAT-ANDERSON Incorporated of Arlington, Virginia, for the Permits and State Programs Division, Office of Solid Waste. Most of the information in the cited documents addresses technical aspects of corrective or remedial actions. However, some documents also focus on procedural aspects of program implementation. Because some technical documents were prepared a number of years ago, Agency policy contained in those documents may not reflect current policy. Therefore, documents listed in this Compendium should be used only for their technical information. 


\section{Introduction}

Throughout the past decade, several offices within the U.S. Environmental Protection Agency (EPA) have been involved in hazardous waste management technologies research, remedial action at chemically contaminated sites, and regulatory development for permitting hazardous waste management facilities. The primary offices involved in these activities include the Office of Research and Development (ORD) and the Office of Solid Waste and Emergency Response (OSWER). During this period, substantial knowledge and experience have been gained relevant to the applicability of remedial action technologies in various environmental settings.

Currently, OSWER is developing regulations on corrective action for solid waste management units-Section 3004(u) of the Hazardous and Solid Waste Amendments (HSWA) to the Resource Conservation and Recovery Act (RCRA). The Corrective Action program consists of three primary phases: (1) the RCRA Facility Assessment (RFA), which is aimed at identifying known and suspected releases of hazardous wastes or hazardous constituents to the environment; (2) the RCRA Facility Investigation (RFI), which consists of media-specific field investigations to characterize the nature, extent, and rate of contaminant migration through the various environmental media; and (3) Corrective Measures Study/Implementation. This last phase, generally termed Corrective Measures, consists of actions undertaken by both facility owners or operators and regulatory agencies that are aimed at selecting and implementing appropriate remedies at facilities subject to RCRA permitting requirements that have contaminant releases of concern. Detailed regulations and guidance for implementing this phase are currently being prepared by OSWER.

The purpose of this summary of ORD and OSWER documents relevant to RCRA corrective action is to provide Regional and State regulatory personnel and facility owners or operators with a concise overview of the available guidances and technical reports on remedial action technologies, site assessment, health assessment, construction techniques and procedures, costing techniques, and quality assurance/quality control procedures. The purpose, scope, and technical approach of the more than 50 documents have been summarized. Also, the applicability of each document to RCRA corrective measures implementation has been evaluated. Copies of the complete documents listed in this Compendium may be obtained at the addresses and telephone numbers given below:

- ORD published documents can be obtained through the ORD Publications Department at:

U.S. EPA

ORD Publications

Cincinnati, $\mathrm{OH} 45268$

(513) 569-7562 (commercial) or 684-7562 (FTS) 
Requesters should have correct publication numbers (and titles, if known) for " 600 " and " 540 " series documents. Three or fewer documents may be requested by phone. Written requests may also be sent to the above address, particularly when requesting more than three documents.

- Guidance documents in the " 530 " series and OSWER Policy Directives in the " 9400 " and "9500" that are not available from NTIS, can be obtained by writing the RCRA Docket Information Center or by writing or calling the RCRA /Superfund Hotline at 1-800-424-9346.

U.S. EPA

RCRA Docket Information Center (OS-305)

401 M Street, S.W.

Washington, DC 20460

- Most documents have designated National Technical Information Service (NTIS) numbers. Generally, any document with a "PB" number must be purchased at:

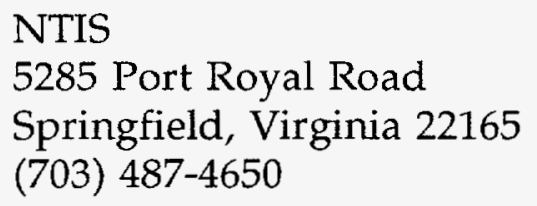

In addition to the documents included in this Compendium, the various EPA offices have developed supplementary technical guidances. In October 1987, OSWER issued the Hazardous Waste Bibliography, which classifies the various documents into four separate lists that distinguish the documents' utility and currency. All documents in the "A Prime" and " $\mathrm{A}$ " lists (that is, those documents considered the most frequently consulted and the most critical to the program) that have not been included in this Compendium are listed in Appendix A. For further information on these documents, the reader should consult the Hazardous Waste Bibliography.

Table 1-1 lists the documents included in this Compendium, classified in the following categories:

- Remedial Action Technical Guidance: Multimedia

- Remedial Action Technical Guidance: Media-Specific

- Site Assessment and Health Assessment

- Construction Techniques/Procedures

- Costing Techniques

- Quality Assurance/Quality Control Guidance Documents

- Program Guidance Documents 
Table 1-1-ORD and OSWER Documents Relevant to RCRA Corrective Action (Page 1 of 3)

\begin{tabular}{|c|c|c|c|}
\hline Category & Document Title & $\begin{array}{c}\text { Issuing } \\
\text { Office }\end{array}$ & Page \\
\hline \multirow{9}{*}{$\begin{array}{l}\text { Remedial Action } \\
\text { Technical Guidance: } \\
\text { Multimedia }\end{array}$} & $\begin{array}{l}\text { Mobile Treatment Technologies for } \\
\text { Superfund Wastes }\end{array}$ & OSWER/OERR & 7 \\
\hline & $\begin{array}{l}\text { Guidance on Cleanup of Surface Tank } \\
\text { and Drum Sites }\end{array}$ & OSWER/OERR & 9 \\
\hline & $\begin{array}{l}\text { Guidance Document on Cleanup of Surface } \\
\text { Impoundment Sites }\end{array}$ & OSWER/OERR & 11 \\
\hline & $\begin{array}{l}\text { Modeling Remedial Actions at Uncontrolled } \\
\text { Hazardous Waste Sites }\end{array}$ & OSWER/OERR/ORD & 13 \\
\hline & $\begin{array}{l}\text { Slurry Trench Construction for Pollution } \\
\text { Migration Control }\end{array}$ & ORD/HWERL & 15 \\
\hline & $\begin{array}{l}\text { Compatibility of Grouts with Hazardous } \\
\text { Wastes }\end{array}$ & ORD/HWERL & 17 \\
\hline & $\begin{array}{l}\text { Systems to Accelerate In-Situ Stabilization } \\
\text { of Waste Deposits }\end{array}$ & ORD/HWERL & 19 \\
\hline & $\begin{array}{l}\text { Handbook for Evaluating Remedial Action } \\
\text { Technology Plans }\end{array}$ & ORD/MERL & 21 \\
\hline & RCRA Corrective Action Interim Measures & OSWER/OWPE & 23 \\
\hline
\end{tabular}

Remedial Action

Technical Guidance:

Media-Specific

Groundwater

Leachate Plume Management

ORD/RREL 28

Management of Hazardous Waste Leachate

OSWER/ORD/MERL

Corrective Measures for Releases to Ground OSWER/OSW Water from Solid Waste Management Units

Guidance on Remedial Actions for

OSWER/OERR

Contaminated Ground Water at

Superfund Sites

Surface Water

Discharge of Waste Water from CERCLA

OSWER/OERR

Sites into Publicly Owned Treatment Works (POTWs)

Corrective Measures for Releases to

OSWER/OSW 
Table 1-1-ORD and OSWER Documents Relevant to RCRA Corrective Action (Page 2 of 3 )

\begin{tabular}{|c|c|c|c|}
\hline Category & Document Title & $\begin{array}{l}\text { Issuing } \\
\text { Office }\end{array}$ & Page \\
\hline \multirow[t]{6}{*}{ Soils } & $\begin{array}{l}\text { Treatment of Contaminated Soils with } \\
\text { Aqueous Surfactants }\end{array}$ & ORD/HWERL & 39 \\
\hline & $\begin{array}{l}\text { Handbook for Stabilization/Solidification } \\
\text { of Hazardous Waste }\end{array}$ & ORD/HWERL & 41 \\
\hline & $\begin{array}{l}\text { Corrective Measures for Releases to Soil } \\
\text { from Solid Waste Management Units }\end{array}$ & OSWER/OSW & 43 \\
\hline & $\begin{array}{l}\text { Review of In-Place Treatment Techniques } \\
\text { for Contaminated Surface Soils, } \\
\text { Volume 1-Technical Evaluation }\end{array}$ & ORD/HWERL & 45 \\
\hline & $\begin{array}{l}\text { Review of In-Place Treatment Techniques } \\
\text { for Contaminated Surface Soils, } \\
\text { Volume 2-Background Information for } \\
\text { In-Situ Treatment }\end{array}$ & ORD/HWERL & 47 \\
\hline & $\begin{array}{l}\text { Technical Resource Document: Design, } \\
\text { Construction, and Operation of Hazardous } \\
\text { and Non-hazardous Waste Surface Impounc }\end{array}$ & $\begin{array}{l}\text { OSWER/ORD/RREL } \\
\text { dments }\end{array}$ & 49 \\
\hline \multirow[t]{2}{*}{ Air } & $\begin{array}{l}\text { In-Situ Methods to Control Emissions } \\
\text { from Surface Impoundments and Landfills }\end{array}$ & ORD/HWERL & 50 \\
\hline & $\begin{array}{l}\text { Technical Guidance for Corrective Measures- } \\
\text { Determining Appropriate Technology and } \\
\text { Response for Air Releases }\end{array}$ & OSWER/OSW & 52 \\
\hline Subsurface Gas & $\begin{array}{l}\text { Technical Guidance for Corrective Measures- } \\
\text { Subsurface Gas }\end{array}$ & OSWER/OSW & 54 \\
\hline \multirow[t]{4}{*}{$\begin{array}{l}\text { Site Assessment and } \\
\text { Health Assessment }\end{array}$} & $\begin{array}{l}\text { Guidance for Conducting Remedial } \\
\text { Investigations and Feasibility Studies } \\
\text { (RI/FS) Under CERCLA }\end{array}$ & ORD/OERR/OWPE & 59 \\
\hline & $\begin{array}{l}\text { Human Health Evaluation Manual, } \\
\text { Volumes I and II }\end{array}$ & OSWER/OERR & 61 \\
\hline & Superfund Exposure Assessment Manual & OSWER/OERR & 63 \\
\hline & Endangerment Assessment Handbook & OSWER/OWPE & 65 \\
\hline Construction & Field Standard Operating Procedures (FSOP) & OSWER/OERR & 69 \\
\hline \multirow[t]{2}{*}{ Techniques/Procedures } & RCRA Facility Assessment (RFA) Guidance & OSWER/OSW & 71 \\
\hline & RCRA Facility Investigation (RFI) Guidance & OSWER/OSW & 73 \\
\hline \multirow[t]{2}{*}{ Costing Techniques } & Remedial Action Costing Procedures Manual & OSWER/OERR & 76 \\
\hline & Removal Cost Management Manual & OSWER/OERR & 78 \\
\hline
\end{tabular}


Table 1-1-ORD and OSWER Documents Relevant to RCRA Corrective Action

(Page 3 of 3 )

\begin{tabular}{|c|c|c|}
\hline Category & Document Title & $\begin{array}{l}\text { Issuing } \\
\text { Office }\end{array}$ \\
\hline
\end{tabular}

QA/QC Guidance

Documents

Program Guidance

Documents
A Compendium of Superfund Field Operations

Data Quality Objectives for Remedial Response Activities, Volumes 1 and 2 User's Guide to the Contract Laboratory Program

RCRA Corrective Action Plan

Stabilization Technologies for RCRA Corrective Actions

National Contingency Plan (NCP), 40 CFR Part 300

Superfund Remedial Design and Remedial Action Guidance

Community Relations in Superfund: A Handbook (Interim Guidance)

Superfund Federal-Lead Remedial Project Management Handbook

Superfund State-Lead Remedial Project Management Handbook

State and Local Involvement in the Superfund Program

Policy on Floodplains and Wetlands Assessments for CERCLA Actions Interim Guidance on Potentially Responsible Party Participation in Remedial Investigations and Feasibility Studies/Revisions to the Interim Guidance on PRP Participation in Remedial Investigations and Feasibility Studies
OSWER/OERR

OSWER/OERR/OWPE

OSWER/OERR

OSWER/OWPE

ORD/CERI

OSWER/OERR

OSWER/OERR

OSWER/OERR

OSWER/OERR

OSWER/OERR

OSWER/OERR

OSWER/OERR 102

OSWER/OWPE 103 


\section{Remedial Action Technical Guidance: Multimedia}

This section reviews and summarizes a total of 10 multimedia remedial action technical guidance documents with respect to their applicability to the RCRA corrective measures program. Generally, these documents would be especially useful during the evaluation and selection of potential corrective measures. The documents describe various corrective measure technologies that can be implemented during corrective measures activities, including mobile treatment technologies, slurry trench construction, and in-situ waste stabilization. These summaries follow. 


\section{Guidance Document Name:}

Mobile Treatment Technologies for Superfund Wastes EPA/540/2-86/003F (PB87-135859)

\section{Originating Office:}

U.S. EPA, Office of Solid Waste and Emergency Response, Office of Emergency and Remedial Response

Status: Final, September 1986

Environmental Media Covered: Soil, air, ground water, surface water

\section{Purpose of the Guidance Document:}

- Provides an overview of currently and potentially available mobile treatment technologies for use on Superfund sites.

- Discusses the capabilities and limitations of five broad treatment categories and specific technologies within each category.

\section{Scope of the Guidance Document:}

- Intended to provide project planners, on-scene coordinators, and remedial project managers with information on the applicability and capabilities of mobile treatment as an alternative to land disposal. Would be most useful during the feasibility study phase of a Superfund remedial action.

\section{Technical Approach:}

- Technologies for thermal treatment, immobilization, chemical treatment, physical treatment, and biological treatment are discussed. Each technology description includes-

- Process description

- Waste type handled

- Restrictive waste characteristics

- Required onsite facilities/capabilities

- Environmental impacts

- Costs

- Commercial applications 


\section{Comparison With Relevant Documents:}

- This provides a more detailed discussion than does the "Superfund Strategy" (U.S. OTA, 1985) on the waste types (including particular chemicals) for which each treatment process can be used. This also discusses required onsite capabilities (such as electrical and water supplies or pumps) for each mobile technology.

\section{Applicability to RCRA Corrective Measures:}

- This provides information on mobile treatment technologies to be used as an alternative to land disposal or permanent onsite treatment units.

- This is most useful during the corrective measures study of a RCRA corrective action. 


\section{Guidance Document Name:}

Guidance on Cleanup of Surface Tank and Drum Sites

EPA/9380.0-03 (PB87-110672)

\section{Originating Office:}

U.S. EPA, Office of Solid Waste and Emergency Response, Office of Emergency and Remedial Response

Status: Final, May 1985

\section{Environmental Media Covered:}

Does not specifically address any environmental media. Primary focus is containerized waste treatment.

\section{Purpose of the Guidance Document:}

- Provides a concise description of the necessary steps to implement surface remedial actions for the cleanup of surface tanks and drums within the provisions of the National Contingency Plan.

- Designed to be used under the direction of any engineer or scientist experienced in hazardous waste remedial projects.

\section{Scope of the Guidance Document:}

- Provides guidance for conducting a limited remedial investigation and a limited feasibility study (a limited remedial investigation refers to an investigation of one problem area or source of contamination at a facility, within a relatively short time period, and a limited feasibility study corresponds to a limited remedial investigation).

- Provides general guidance on the basic approach to developing contracts for remedial actions at tank and drum sites.

- Presents a generic process for choosing treatment technologies for uncontrolled tank and drum sites.

\section{Technical Approach:}

- Flow charts are used to present a logical sequence of decisions and activities for the implementation of remedial actions.

- Section 2.0 reviews the steps to conduct a remedial investigation to estimate the characteristics and quantities of wastes stored in aboveground tanks and drums. 
- Section 3.0 presents steps for the evaluation and recommendation of a cost-effective and environmentally sound remedial alternative for wastes stored in drums and tanks.

- Section 4.0 reviews typical remedial design and remedial action issues that may be unique to tank and drum sites.

\section{Comparison With Relevant Documents:}

- This document is designed to be used in conjunction with EPA's guidance documents on conducting remedial investigations: "Guidance for Conducting Remedial Investigations and Feasibility Studies Under CERCLA."

\section{Applicability to RCRA Corrective Measures:}

- Because the document addresses only containerized waste treatment, it would be most useful in outlining the special considerations required for implementing corrective measures for RCRA tank storage units. 


\section{Guidance Document Name:}

Guidance Document on Cleanup of Surface Impoundment Sites EPA/9380.0-06 (PB87-110664)

\section{Originating Office:}

U.S. EPA, Office of Solid Waste and Emergency Response, Office of Emergency and Remedial Response

Status: Final, July 1986

Environmental Media Covered: Soil, ground water

\section{Purpose of the Guidance Document:}

- Provides a concise definition of the necessary steps to implement surface remedial actions for the cleanup of surface impoundments under CERCLA.

\section{Scope of the Guidance Document:}

- Provides a systematic approach for conducting a limited remedial investigation and a limited feasibility study at National Priorities List sites having one or more surface impoundments.

\section{Technical Approach:}

- Presents a classification scheme designed to evaluate the complexity of a surface impoundment site, which will determine the required scope of the limited remedial investigation. This classification scheme is based on-

- Depth to ground-water table

- Integrity of surface impoundment

- Permeability of soils

- Discusses the four main components of a limited remedial investigation in terms of their purpose, techniques, and limitations. Steps for a limited remedial investigation are outlined in a flow diagram.

- Provides guidance for the evaluation and selection of an appropriate remedy, either temporary or final.

\section{Comparison With Relevant Documents:}

- This is designed to be used in conjunction with EPA's guidance documents on conducting remedial investigations and feasibility studies-for example, "Guidance for Conducting Remedial Investigations and Feasibility Studies Under CERCLA." 


\section{Applicability to RCRA Corrective Measures:}

- This is useful in evaluating potential corrective measures for releases from surface impoundments. 


\section{Guidance Document Name:}

Modeling Remedial Actions at Uncontrolled Hazardous Waste Sites EPA/540/2-85/001 (PB85-211357)

\section{Originating Office:}

U.S. EPA, Office of Solid Waste and Emergency Response, Office of Emergency and Remedial Response, Office of Research and Development

Status: Final, April 1988

\section{Environmental Media Covered:}

Surface water, ground water, and soil; air and fugitive dust emissions are discussed peripherally, but the reader is referred to other documents for a detailed discussion of these media.

\section{Purpose of the Guidance Document:}

- Provides guidance on the selection and use of models for the purpose of evaluating the effectiveness of remedial actions at uncontrolled hazardous waste sites.

\section{Scope of the Guidance Document:}

- Is most useful in the feasibility study portion of a Superfund remedial action.

- Provides guidance to State and Regional staff on the need for and the selection and use of analytical and numerical methods for modeling remedial actions.

- Addresses modeling assumptions and limitations, required model dimensionality, resource availability, and data needs.

Technical Approach:

Volume 1-Selection of Models for Remedial Assessment

- Provides model selection methodology based on flow charts and matrices and guidance for State or Regional staff in assessing the need for predictive models at uncontrolled hazardous waste sites.

Volume 2-Simplified Methods for Subsurface and Waste Control Actions

- Compilation of analytical and semi-analytical methods for evaluating subsurface and waste control remedial actions, addressing model assumptions and limitations. 
Volume 3-Numerical Modeling of Surface, Subsurface, and Waste Control Actions

- Guidance for use of numerical models for sites where more detailed analyses are required and where sufficient resources are available.

Volume 4-Analytical and Numerical Models for the Evaluation of Remedial Actions in Surface Water

- Guidance for modeling remedial actions at sites with surface-water contamination.

\section{Comparison With Relevant Documents:}

- This is broader in applicability and interpretation than other remedial action technical quidance documents. Numerical and analytical modeling techniques could be applied to a variety of remedial action techniques and environmental media.

\section{Applicability to RCRA Corrective Measures:}

- This would be useful in the preliminary stages of a corrective measures study to evaluate which models are appropriate to predict contaminant transport and to predict the effectiveness of proposed corrective measures. 


\section{Guidance Document Name:}

Slurry Trench Construction for Pollution Migration Control EPA/540/2-84/001 (PB84-177831)

\section{Originating Office:}

U.S. EPA, Office of Research and Development, Hazardous Waste Engineering Research Laboratory

Status: Final, February 1984

Environmental Media Covered: Ground water

\section{Purpose of the Guidance Document:}

- Provides reviewers of remedial action plans with the necessary background material to evaluate portions of the plan addressing pollution migration control slurry walls.

\section{Scope of the Guidance Document:}

- Discusses early development and use of slurry trench construction techniques.

- Describes the following-

- What types of slurry walls can be expected to help control pollution migration

- Current theories regarding the functions of bentonite slurries and various backfill materials

- Typical slurry wall configurations

- Other slurry wall configurations

- Other remedial measures appropriate for use in conjunction with slurry walls

- Procedures for planning a slurry wall configuration

\section{Technical Approach:}

- Discusses properties and performance of three primary types of slurries: bentonite, soil-bentonite, and cement-bentonite.

- Describes vertical and horizontal slurry wall configurations.

- Discusses associated remedial measures and practices, such as ground-water pumping, collection and drainage systems, and surface sealing. 
- Describes types and extent of site investigation and characterization necessary to determine the feasibility of using a slurry wall, including-

- Physical constraints

- Subsurface investigations

- Wastes and leachates

- Compatibility testing

- Describes slurry wall design and construction techniques.

- Discusses the need for and requirements of a slurry wall monitoring and maintenance program.

- Itemizes the cost elements of installing a slurry wall, such as-

- Unit cost

- Construction activities

- Materials

- Equipment

\section{Comparison With Relevant Documents:}

- The focus of this document is on traditional (that is, construction industry) application and designs for slurry walls, as compared with "Compatibility of Grouts With Hazardous Wastes" (EPA, 1984), which discusses the known effects of chemical groups commonly found in landfill leachate on the setting time and durability of common slurries or grouts.

\section{Applicability to RCRA Corrective Measures:}

- This would be useful during the study and selection of potential corrective measures and during the development of corrective measures design.

- This describes appropriate situations for the use of slurry walls, the properties and performance of slurry walls, and the need for monitoring and maintaining various types of slurry walls. 


\section{Guidance Document Name:}

Compatibility of Grouts with Hazardous Wastes

EPA/600/2-84/015 (PB84-139732)

\section{Originating Office:}

U.S. EPA, Office of Research and Development, Hazardous Waste Engineering Research Laboratory

Status: Final, January 1984

Environmental Media Covered: No direct discussion of any environmental medium

Purpose of the Guidance Document:

- Compiles data on the compatibility and durability of grouts in the presence of hazardous wastes and leachates, and summarizes the test procedures available to measure grout durability.

\section{Scope of the Guidance Document:}

- Presents the known effects of chemical groups commonly found in landfills on the setting time and durability of each grout in a soil matrix.

- Describes the laboratory tests that should be performed to establish the compatibility of chemicals with grouts.

- Would be most useful during the feasibility study and remedial investigation stages of a Superfund action.

\section{Technical Approach:}

- Discusses 12 kinds of grouts in terms of-

- Physical and chemical properties

- Reaction theory

- Known chemical compatibility

- Uses a series of matrices to present the known and predicted effects of different chemical groups on the setting time and durability of the various grouts currently in use.

- Describes the laboratory tests that should be performed to establish the compatibility of chemicals with grouts, including a very general discussion of advantages, disadvantages, and sources of error associated with different testing methods. 


\section{Comparison With Relevant Documents:}

- This document provides the guidance necessary to determine waste/slurry compatibility through treatability studies, as compared with "Slurry Trench Construction for Pollution Migration Control," which contains guidance for traditional slurry wall design and construction.

\section{Applicability to RCRA Corrective Measures:}

- This would provide guidance for the design of a remedy selected during a corrective measures study; in particular, it would provide a methodology for performing a treatability study to determine waste/grout compatibility for a particular corrective measure. 


\section{Guidance Document Name:}

Systems to Accelerate In-Situ Stabilization of Waste Deposits EPA/540/2-86/002 (PB87-112306)

\section{Originating Office:}

U.S. EPA, Office of Research and Development, Hazardous Waste Engineering Research Laboratory

Status: Final, September 1986

Environmental Media Covered: Ground water, soil

\section{Purpose of the Guidance Document:}

- Provides the essential elements of in-situ waste stabilization methods-

- Selection of a chemical or biological agent that can react with and stabilize the waste

- Method for the delivery of the reactant to the deposit

- Method for the recovery of the reaction products or mobilized wastes

\section{Scope of the Guidance Document:}

- Serves as a guidance document with respect to potential technologies for in-situ waste stabilization as they currently exist (that is, in their conceptual or developmental stage).

- Presents a methodology for the selection of delivery and recovery systems.

- Would be useful during the remedial investigation and feasibility study stages of a Superfund action.

\section{Technical Approach:}

- Briefly describes several delivery/recovery systems in terms of the hydrogeologic/soil features, including depth of the waste deposit from the surface and depth to the water table, that would give preference to that method. Quantitative methods are described for determining the hydrogeologic parameters. 
- Gives information taken form the literature, reports on demonstration studies, and personal communications on-

- Biodegradation methods

- Surfactant-assisted flushing

- Hydrolysis

- Chemical oxidation

- Provides guidance on the use of stabilization technologies at specific sites.

\section{Comparison With Relevant Documents:}

- This is similar in scope to the "Handbook for Stabilization/Solidification of Hazardous Waste" and "Review of In-Place Treatment Techniques for Contaminated Surface Soils," Volumes 1 and 2. Although similar in methodology to this guidance document, the "Handbook for Stabilization/Solidification of Hazardous Waste" is not limited to in-place stabilization techniques. "Review of In-Place Treatment Techniques for Contaminated Surface Soils," Volumes 1 and 2, provides the most detailed discussion of the soil and waste characteristics that affect contaminant transport and fate.

\section{Applicability to RCRA Corrective Measures:}

- This would be useful during a corrective measures study.

- This would have limited applicability for corrective measures implementation, although the document is more geared toward the planning stages of a RCRA corrective action. 


\section{Guidance Document Name:}

Handbook for Evaluating Remedial Action Technology Plans

EPA/500/2-82/076 (PB84-118249)

\section{Originating Office:}

U.S. EPA, Office of Research and Development, Municipal Environmental Research Laboratory

Status: Draft, August 1983

Environmental Media Covered: Ground water, surface water, contaminated soil, air

\section{Purpose of the Guidance Document:}

- Provides an outline of technical information that potentially could be used to evaluate long-term remedial action plans for controlling or treating wastes or leachates at uncontrolled hazardous waste sites. Intended audience includes those involved in the review of preliminary engineering reports on formal designs of remedial actions at the waste sites.

\section{Scope of the Guidance Document:}

- Contains information on more than 50 remedial action technologies. A brief description, status, factors for determining feasibility and reliability, principal data requirements, and basic information for cost review are given for each technology. In addition, a general discussion of the pathways and associated remedial approaches and monitoring techniques has been included, organized by media.

\section{Technical Approach:}

- Section 2 describes general approaches to remedy problems in five media that can become contaminated by hazardous substances released at an uncontrolled site: ground water/leachate, surface water, soil, waste, and air. Sections 3 and 4 describe individual technologies and engineering methods. Section 3 describes technologies for the physical control and containment of hazardous constituents in the five media. Section 4 describes treatment technologies for leachate, waste, and contaminated soil. Information in Sections 3 and 4 is presented in the following format-

- Description of the technology

- Availability of the technology

- Feasibility and effectiveness - technical factors important in understanding and reviewing the technology

- Major factors that determine the performance of the technology

- Site-specific data necessary for the design of the technology

- Information for analyzing technology cost estimates 
- Section 5 presents a general discussion of monitoring techniques for use during remedial activities and during the postclosure custodial period. A discussion of monitoring wells in the format of Sections 3 and 4 is also provided.

\section{Comparison With Relevant Documents:}

- This document is more specific in applicability than "Guidance for Conducting Remedial Investigations and Feasibility Studies Under CERCLA." Unlike that document, this document does not provide a methodology for the development for remedial alternatives. However, it does provide technical evaluations of more than 50 remedial action alternatives.

\section{Applicability to RCRA Corrective Measures:}

- This is useful in all phases of a corrective measures study, from the preliminary consideration of a variety of treatment technologies to the evaluation of selected corrective measures. It is particularly useful for Agency review of the feasibility, expected performance, design, and cost of alternatives proposed by the owner/ operator in a corrective measures study.

- It has limited use in the implementation of corrective measures; it describes monitoring techniques and postclosure custodial care. 


\section{Guidance Document Name:}

RCRA Corrective Action Interim Measures

Control No. 9902.4 (PB91-139881)

\section{Originating Office:}

U.S. EPA, Office of Solid Waste and Emergency Response, Office of Waste Programs Enforcement

Status: Final, June 1987

\section{Environmental Media Covered:}

Ground water, surface water, soils, air, gas migration

\section{Purpose of the Guidance Document:}

- For use by Regional (and State) enforcement staff for developing language in RCRA §3008(h) enforcement orders for guiding the implementation of interim measures. Specific interim measures for the following types of waste management units are specified-

- Containers

- Surface impoundments

- Landfills

- Waste piles

- Tanks

- In addition, interim measures have been identified for the following media and/or pollution events-

- Ground water

- Surface water

- Gas migration

- Air emissions

\section{Scope of the Guidance Document:}

- Identifies and lists the various types of interim measures that have been used at various Superfund sites for potential use at RCRA sites.

\section{Technical Approach:}

- An implementation strategy and a set of decision criteria for use in the development of interim measures language in RCRA $\$ 3008(\mathrm{~h})$ orders or permits are identified. A set of 11 questions for assisting Regional staff in reviewing pertinent facts about the facility and in assessing the need for interim measures is given. 
- Enforcement order language is given for multiple interim measures techniques for each of the waste management units, environmental media, and pollution events listed above.

\section{Comparison With Relevant Documents:}

- The ORD and OERR handbook titled "Remedial Action at Waste Disposal Sites" provides technical information on the advantages and disadvantages of many of the techniques identified in this document. That handbook also provides details on "permanent" solutions.

\section{Applicability to RCRA Corrective Measures:}

- This draft guidance is a useful listing of potential interim measures that may be implemented at RCRA facilities undergoing corrective action.

- Measures specified in a $\$ 3008(\mathrm{~h})$ order should be coordinated with the Regional and/or State permit writer(s) to ensure compatibility with long-term corrective measures implementation plans. 


\section{Remedial Action Technical Guidance: Media-Specific}

This section includes a total of 16 media-specific guidance documents issued by OERR, ORD, and OSWER. These documents are especially useful for the evaluation and selection stages of a corrective measures study. In general, the documents by themselves do not provide adequate technical detail for corrective measures implementation. Among the remedial technologies discussed are those for contaminated ground water, surface water, soil, and air and for the migration of subsurface gas. The following summaries include individual assessments of the applicability of the documents to RCRA program corrective measures implementation. 


\section{Guidance Document Name:}

Leachate Plume Management

EPA/540/2-85/004 (PB86-122330)

\section{Originating Office:}

U.S. EPA, Office of Research and Development, Risk Reduction Engineering Laboratory

Status: Final, November 1985

Environmental Media Covered: Ground water

\section{Purpose of the Guidance Document:}

- Provides government and industry personnel with the means to successfully control leachate plumes from uncontrolled hazardous waste sites.

\section{Scope of the Guidance Document:}

- Provides an overview of the fundamental concepts, procedures, and technologies used in leachate plume management.

Technical Approach:

- Discusses plume dynamics-

- Ground-water flow patterns

- Effects of leachate characteristics

- Discusses plume delineation procedures and data.

- Discusses plume control technologies.

- Discusses theory and design of ground-water pumping, subsurface drains, and low-permeability barriers.

\section{Comparison With Relevant Documents:}

- This document provides a more thorough treatment of the hydrogeologic factors affecting leachate flow than does "Management of Hazardous Waste Leachate" (SW-871), which mainly addresses leachate treatment alternatives. 


\section{Applicability to RCRA Corrective Measures:}

- This provides background information on the theory and design of potential corrective measures to address ground-water contamination resulting from leachate plumes. 


\section{Guidance Document Name:}

Management of Hazardous Waste Leachate (SW-871R)

PB91-181578

\section{Originating Office:}

U.S. EPA, Office of Solid Waste and Emergency Response, Office of Solid Waste

Status: Final, August 1980

Environmental Media Covered: Leachate in ground water

\section{Purpose of the Guidance Document:}

- Provides guidance for permit officials and disposal site operators on available management options for controlling, treating, and disposing of hazardous waste leachates.

\section{Scope of the Guidance Document:}

- Provides overviews of leachate generation and characteristics.

- Presents alternatives for leachate treatment and disposal.

- Provides broad guidance for the design of a monitoring program.

- In general, provides narrative qualitative discussions of treatment alternatives and refers the reader to other documents for the technical detail necessary for the selection or implementation of a treatment alternative.

Technical Approach:

- Presents a broad discussion of three hazardous waste leachate management options-

- Treatment as hazardous waste

- Onsite management

- Leachate treatment/disposal

- Presents a treatment process applicability matrix that rates the effectiveness of different treatment processes for different chemical waste types as good, fair, poor, or variable.

- Presents a matrix of treatment process versus residuals and gaseous emissions generated. 
- Presents a flow chart of leachate treatment process selection methodology based on-

- Evaluation of leachate quality

- Treatability studies

- Pilot-scale studies

- Full-scale studies

\section{Comparison With Relevant Documents:}

- This document should be used in conjunction with "Leachate Plume Management," which provides a more rigorous treatment of the hydrogeologic factors affecting leachate plume development.

\section{Applicability to RCRA Corrective Measures:}

- This document has limited applicability, but it might be useful as a bibliography of other guidance documents; however, much material contained within may be outdated. 


\section{Guidance Document Name:}

Corrective Measures for Releases to Ground Water from Solid Waste Management Units

EPA/530/SW-88/020 (PB88-185251)

\section{Originating Office:}

U.S. EPA, Office of Solid Waste and Emergency Response, Office of Solid Waste

Status: Draft final

Environmental Media Covered: Ground water

Purpose of the Guidance Document:

- Uses technology assessments and case studies to evaluate the relative success or failure of each technology for various hydrologic settings and waste types.

\section{Scope of the Guidance Document:}

- Describes the steps involved in assessing the need for corrective measures at solid waste management units.

- Provides an overview of corrective measures applicable to releases to ground water at solid waste management units.

\section{Technical Approach:}

- Describes the steps involved in assessing the need for corrective measures-

- Source characterization

- Hazardous constituent distribution

- Fate and transport mechanisms

- Receptor identification

- Risk assessment

- Both source control technologies and ground-water control/treatment technologies are described in terms of -

- Status of technology (that is, emerging, proven)

- Hydrogeologic/hazardous constituent applicability

- Additional remedial measures required

- Effectiveness 
- Case study reports include-

- Site characteristics

- Soils

- Geology

- Hydrology

- Releases

- Types and causes of releases

- Mechanisms for detection

- Extent of contamination

- Remedial actions

- Response

- Success/failure

\section{Comparison With Relevant Documents:}

- This is part of a group of documents that addresses releases to air, surface water, ground water, and soil. By itself, this document does not provide adequate technical detail to select or implement a corrective measure so it should be used in conjunction with other technical guidance documents listed in this Compendium.

\section{Applicability to RCRA Corrective Measures:}

- This document evaluates the relative success or failure for various ground-water corrective measures technologies for various hydrologic settings and waste types. 


\section{Guidance Document Name:}

Guidance on Remedial Actions for Contaminated Ground Water at Superfund Sites EPA/540/G-88/003 (PB89-184618)

\section{Originating Office:}

U.S. EPA, Office of Solid Waste and Emergency Response, Office of Emergency and Remedial Response

Status: Final, December 1988

Environmental Media Covered: Ground water

\section{Purpose of the Guidance Document:}

- Describes how to develop, evaluate, and select remedial actions for ground-water remediation under the Superfund program.

- Provides guidance and key considerations to be addressed when selecting a ground-water remedy during the CERCLA feasibility study of alternatives.

- Helps ensure that the most cost-effective alternative is chosen during Superfund activities.

\section{Scope of the Guidance Document:}

- The document is intended for an audience of-

- Contractors planning and executing CERCLA remedial investigations and feasibility studies

- EPA Regional project managers responsible for the quality and completeness of remedial investigations and feasibility studies

- EPA Regional project managers and other decisionmakers responsible for the selection and performance evaluation of ground-water remedial actions

- Relevant to CERCLA remedial investigations and feasibility studies.

\section{Technical Approach:}

- Identifies the type of ground-water problems at the site, including the type of chemicals present and the horizontal and vertical extent of contamination.

- Remedial alternatives that remedy ground-water problems are developed from individual technologies that address site-specific problems. 
- Remediation targets for carcinogens range from $10^{-4}$ to $10^{-7}$ excess lifetime cancer risk; remediation targets for noncarcinogens are set according to applicable standards and criteria.

- Remediation targets are achieved within an acceptable period of time in the area of attainment (that is, the area between the waste source and the boundary of the plume.) Ground water with characteristics of Class I aquifers are expected to be restored most rapidly (for example, within 1 to 5 years).

- Ground-water remediation levels must be determined before the effectiveness of remedial actions can be evaluated. Remediation levels are defined by applicable or relevant and appropriate Federal requirements.

- The choice of a remediation alternative depends on the following criteria for evaluation-

- Class of ground water affected-Type I, II, or III

- Availability of alternative water supply

- Ability to control/monitor plume movement

- Future ground-water uses

- Effectiveness of institutional controls

- Other health risks borne by the affected population

- Costs

- Technical effectiveness of ground-water restoration

- Potential for plume spreading

- Performance monitoring

- Hydrogeologic setting

\section{Comparison With Relevant Documents:}

- The development and evaluation of remedial actions for contaminated ground water should be performed in accordance with "Guidance for Conducting Remedial Investigations and Feasibility Studies Under CERCLA."

\section{Applicability to RCRA Corrective Measures:}

- This document would be useful in selecting, evaluating, and developing appropriate cover measures at RCRA facilities with contaminated ground water. 


\section{Guidance Document Name:}

Discharge of Waste Water from CERCLA Sites into Publicly Owned Treatment Works (POTWs)

OSWER Directive No. 9330.2-04 (PB90-249616)

\section{Originating Office:}

U.S. EPA, Office of Solid Waste and Emergency Response, Office of Emergency and Remedial Response

Status: Final, April 15, 1986

Environmental Media Covered: Surface water

Purpose of the Guidance Document:

- Highlights technical and policy concerns expressed in meetings between EPA and the Association of Metropolitan Sewerage Authorities regarding the use and selection of publicly owned treatment works for CERCLA wastewater.

\section{Scope of the Guidance Document:}

- Discusses proposed criteria on the use and selection of publicly owned treatment works for CERCLA wastewater.

\section{Technical Approach:}

- Discusses the National Pretreatment Program requirements applicable to the introduction of nondomestic wastewater into a publicly owned treatment works.

- Discusses points to evaluate in determining whether a publicly owned treatment works may accept wastewater from a CERCLA site.

\section{Comparison With Relevant Documents:}

- This document is unique in scope.

\section{Applicability to RCRA Corrective Measures:}

- This document presents considerations to evaluate prior to remedy selection where the discharge of wastewater from a contaminated site into a publicly owned treatment works is among the alternatives. 


\section{Guidance Document Name:}

Corrective Measures for Releases to Surface Water EPA/530/SW-90/085 (PB91-102046)

\section{Originating Office:}

U.S. EPA, Office of Solid Waste and Emergency Response, Office of Solid Waste

Status: Draft final

Environmental Media Covered: Surface water

Purpose of the Guidance Document:

- Provides guidance to identify the need for corrective measures and to identify mechanisms to correct releases to surface water.

\section{Scope of the Guidance Document:}

- Provides description of the steps necessary in-

- Assessment of the need for corrective measures

- Control of sources of contamination

- Technologies for offsite containment, recovery, and treatment

- Uses case studies to demonstrate how to select and implement corrective measures for releases to surface waters.

Technical Approach:

- Provides a narrative, tabular, and checklist approach to-

- Assessment of the need for corrective measures

- Source control

- Offsite corrective measures

- Case studies are summarized in terms of-

- Types of releases

- Waste types

- Response action

\section{Comparison With Relevant Documents:}

- This is part of a group of documents that addresses releases to air, surface water, ground water, and soil. By itself, this document does not provide adequate technical detail to select or implement a corrective action so it should be used in conjunction with other technical guidance documents in this Compendium. 


\section{Applicability to RCRA Corrective Measures:}

- This document provides guidance for the selection and implementation of corrective measures to address releases to surface water under RCRA, although this document by itself would not provide adequate technical detail for corrective measures selection or implementation. 


\section{Guidance Document Name:}

Treatment of Contaminated Soils with Aqueous Surfactants EPA/600/2-85/12a (PB86-122561)

\section{Originating Office:}

U.S. EPA, Office of Research and Development, Hazardous Waste Engineering Research Laboratory

Status: Interim, November 1985

Environmental Media Covered: Soil, ground water

\section{Purpose of the Guidance Document:}

- Reports the results of bench-scale treatability studies conducted to determine whether the efficiency of water-washing surf-contaminated soils could be enhanced through the use of aqueous surfactants.

- Makes limited recommendations for the selection of such a surfactant for the in-situ treatment of contaminated soils.

\section{Scope of the Guidance Document:}

- Uses a traditional research approach to evaluate methods for the in-situ treatment of contaminated soils.

- Would be most useful as a tool for further research on in-situ treatment methods or full-scale studies at Superfund sites.

\section{Technical Approach:}

- The reports of the study include-

- Results of a literature search on methods for the in-situ treatment of soils contaminated with different waste types

- Results of the laboratory study

- Recommendations for selecting a surfactant for the in-situ treatment of contaminated soils

- Recommendations for further studies

\section{Comparison With Relevant Documents:}

- Unlike other guidance documents (for example, "Mobile Treatment Technologies for Superfund Wastes" (EPA, 1986)), this report is not a guide for selecting the best treatment technology for contaminated soils. Rather, it is a tool for conducting full-scale studies for in-situ treatment at Superfund sites. 


\section{Applicability to RCRA Corrective Measures:}

- This document does not have proven applicability for full-scale corrective actions to address soil contamination at RCRA sites. It would be most useful as a tool for further research. 


\section{Guidance Document Name:}

Handbook for Stabilization/Solidification of Hazardous Waste

EPA/540/2-86/001 (PB87-116745)

\section{Originating Office:}

U.S. EPA, Office of Research and Development, Hazardous Waste Engineering Research Laboratory

Status: Final, June 1986

Environmental Media Covered: Soil/sediment

Purpose of the Guidance Document:

- Provides designers and reviewers of remedial action plans with the information necessary to judge the feasibility of stabilization/solidification technology for the control of pollutant migration from land-based hazardous waste disposal units.

\section{Scope of the Guidance Document:}

- Discusses the general chemical systems involved in stabilization/solidification technologies to provide the background information necessary for the selection of the optimum treatment option for a specific waste.

- Addresses design requirements and preliminary cost estimating for selected stabilization/solidification alternatives.

- Would be most useful during the feasibility study portion of a Superfund action.

Technical Approach:

- Based on field surveys, four stabilization/solidification scenarios are developed and compared in terms of-

- Project sequencing

- Equipment requirements

- Costs

- Special safety and environmental concerns

- Possible modifications of treatment alternatives to reduce cost

- Discusses several waste stabilization/solidification techniques in terms of-

- Chemical basis for technology and commercial formulations in common use

- Waste and site characterizations appropriate for treatment process evaluation

- Protocols for bench-scale testing

- Sampling and testing protocols for assessing containment efficiency

- Final site cleanup and monitoring 


\section{Comparison With Relevant Documents:}

- The focus is on a methodology for corrective measures selection, as in "Systems to Accelerate In-Situ Stabilization of Waste Deposits"; however, this document addresses both in-situ and offsite waste stabilization.

Applicability to RCRA Corrective Measures:

- Monitoring and testing protocols would be useful in evaluating stabilization and solidification as an appropriate remedial alternative. 


\section{Guidance Document Name:}

Corrective Measures for Releases to Soil from Solid Waste Management Units EPA/530/SW-88/022 (PB88-185277)

\section{Originating Office:}

U.S. EPA, Office of Solid Waste and Emergency Response, Office of Solid Waste

Status: August 1985 (Contractor's Final Report)

Environmental Media Covered: Soil

Purpose of the Guidance Document:

- Provides guidance on selecting corrective measures in response to a hazardous constituent release to soil.

\section{Scope of the Guidance Document:}

- Provides parameters and criteria that should be considered in selecting a particular remedial response for specific site conditions and identified compounds.

- Discusses the need for corrective measures through the review of the potential for hazardous constituents released to soil to be transported to other media.

- Provides an overview of corrective measures.

- Discusses case studies where releases to soil have occurred and identifies corrective measures undertaken to clean up the soil.

- Provides recommendations for the application of corrective measures to soil releases.

Technical Approach:

- Describes a stepwise process for assessing the need for corrective measures-

- Source characterization

- Extent of contamination

- Fate and transport

- Exposure assessment

- Hazard (toxicity) assessment and characterization 
- Discusses the various types of removal/containment and treatment technologies that apply to the remediation of releases to soils.

- Proven technologies-successfully used at sites to clean up hazardous wastes from soils

- Imminent technologies-proven in the laboratory and successfully used in the field through pilot-scale studies

- Emerging technologies-currently in the laboratory testing stage

- Reviews case studies that demonstrate how to select and implement corrective measures for releases to soils from solid waste management units.

- Presents recommendations on how to select and implement corrective measures.

- Includes factors to consider in selecting corrective measures for releases to soils, such as-

- Soil conditions

- Site location

- Hydrogeology

- Implementability

- Cost

\section{Comparison With Relevant Documents:}

- This is part of a group of documents that addresses releases to air, surface water, ground water, and soil. By itself, this document does not provide the technical detail to choose or implement a corrective action.

\section{Applicability to RCRA Corrective Measures:}

- This document provides guidance for the selection and implementation of potential corrective measures in response to a contaminant release to soils, although this document by itself would not provide adequate technical detail for corrective measures selection or implementation. 


\section{Guidance Document Name:}

Review of In-Place Treatment Techniques for Contaminated Surface Soils, Volume 1-Technical Evaluation EPA/540/2-84/003 (PB85-124881)

\section{Originating Office:}

U.S. EPA, Office of Research and Development, Hazardous Waste Engineering Research Laboratory

Status: Final, July 1984

\section{Environmental Media Covered:}

Soils, but indirectly addresses ground water, surface water, and air

Purpose of the Guidance Document:

- Discusses the selection of the appropriate in-place treatment technology for a particular site and provides specific information on each technology.

\section{Scope of the Guidance Document:}

- Provides a narrative discussion of different in-place treatment technologies.

- Provides data for estimating costs.

- Discusses engineering practices for modifying soil properties to make in-place treatment more effective.

- Would be most useful during the feasibility study of a Superfund action.

\section{Technical Approach:}

- Contains the following information-

- Process description

- Information requirements for technology application

- Wastes amenable to treatment

- Current status of technology

- Ease of application

- Potentially achievable levels of treatment

- Long-term reliability of the technology

- Secondary impacts

- Required equipment and materials 
- Discusses engineering methods for increasing the effectiveness of in-place treatment by modifying the following properties of soil-

- Oxygen content

- Moisture content

- Nutrient content

- $\mathrm{pH}$

- Soil temperature

\section{Comparison With Relevant Documents:}

- Volumes 1 and 2 are similar in scope to "Review of In-Place Treatment Techniques for Contaminated Surface Soils"; however, these volumes provide a more detailed discussion of the soil and waste characteristics that affect contaminant transport and fate.

\section{Applicability to RCRA Corrective Measures:}

- This document is useful for determining the potential of in-situ treatment technologies to address contaminated soils at a RCRA corrective action site.

- The discussion of engineering methods for modifying soil characteristics to improve the effectiveness of treatment technologies would be useful during the initial or planning stages of corrective measures implementation. 


\section{Guidance Document Name:}

Review of In-Place Treatment Techniques for Contaminated Surface Soils, Volume 2-Background Information for In-Situ Treatment EPA/540/2-84/003B (PB85-124889)

\section{Originating Office:}

U.S. EPA, Office of Research and Development, Hazardous Waste Engineering Research Laboratory

Status: Final, July 1984

\section{Environmental Media Covered:}

Soils, but indirectly addresses ground water, surface water, and air

\section{Purpose of the Guidance Document:}

- Provides background information and related chemical data to support the treatment methodology described in Volume 1.

\section{Scope of the Guidance Document:}

- Presents information on-

- Monitoring to determine treatment effectiveness

- Characterization of the behavior and fate of hazardous constituents in soil waste systems

- Properties for various compounds that affect their interactions with soil adsorption, degradation, and volatilization

- Most useful during the feasibility study and the postclosure monitoring phases of a Superfund action.

\section{Technical Approach:}

- Discusses the specific site and soil characteristics that need to be evaluated when assessing a site for in-situ treatment-

- Soil type and extent

- Soil profile properties

- Hydraulic properties and conditions

- Geological and hydrogeological factors

- Meteorological and climatological data 
- Discusses one-dimensional transport models to describe the behavior of waste constituents in soil systems. These models represent a first-cut approach to ranking waste types with respect to potential mobility and, therefore, treatment priority.

- Includes specific monitoring information for each medium (soil, water, and air) and cost estimates for various monitoring techniques.

- The appendix contains a data base for assessing the soil waste interactions of individual chemicals, describing the following parameters-

- Chemical properties

- Adsorption parameters

- Degradation parameters

- Volatilization parameters

Comparison With Relevant Documents:

- See "Review of In-Place Treatment Techniques for Contaminated Surface Soils," Volume 1.

\section{Applicability to RCRA Corrective Measures:}

- This document provides the technical guidance necessary to select a remedy during a corrective measures study.

- The document provides monitoring information that would be useful in evaluating the effectiveness of an in-situ soil treatment technology. 


\section{Guidance Document Name:}

Technical Resource Document: Design, Construction, and Operation, of Hazardous and Non-Hazardous Waste Surface Impoundments EPA/530/SW-91/054 (PB91-204 354)

\section{Originating Office:}

U.S. EPA, Office of Solid Waste and Emergency Response, Office of Research and Development, Risk Reduction Engineering Laboratory

Status: Final, June 1991

\section{Environmental Media Covered:}

Discusses soils, but only in terms of their appropriateness as cover material

\section{Purpose of the Guidance Document:}

- Provides design guidance on final covers for hazardous waste units. The recommended design satisfies the requirements of 40 CFR 264 and 365, Subparts $\mathrm{G}$ (closure and postclosure), $\mathrm{K}$ (surface impoundments), and N (landfills).

\section{Scope of the Guidance Document:}

- Presents the Agency-recommended final cover system design in detail, as well as considerations for construction quality assurance. Attention is given to erosion, settlement, and subsidence and their potential cover-damaging effects.

Technical Approach:

- A separate section of the document is devoted to the design details of each layer of recommended cover. A discussion of the rationale for the recommended specification is included.

\section{Comparison With Relevant Documents:}

- This is the only guidance document in this Compendium that specifically addresses cover systems.

\section{Applicability to RCRA Corrective Measures:}

- This document would apply to the implementation of a RCRA corrective action with respect to designing covers for closure or cleanup. 


\section{Guidance Document Name:}

In-Situ Methods to Control Emissions from Surface Impoundments and Landfills EPA/600/2-85/124 (PB86-121365)

\section{Originating Office:}

U.S. EPA, Office of Research and Development, Hazardous Waste Engineering Research Laboratory

Status: Final, October 1985

Environmental Media Covered: Air

\section{Purpose of the Guidance Document:}

- Provides the results of a study that included laboratory investigations and literature reviews on methods of reducing emissions of volatile organic compounds (VOC's) from surface impoundments and landfills.

\section{Scope of the Guidance Document:}

- Discusses several in-situ methods for controlling VOC emissions from landfills and surface impoundments, and draws conclusions with respect to the suitability of each method under various circumstances.

\section{Technical Approach:}

- Control methods discussed are-

- Complete enclosure of a surface impoundment

- Use of floating solid objects

- Shape modification for surface impoundments

- Aerodynamic modification (that is, wind barriers)

- Floating oil layers and surfactants

- Synthetic covers for landfills

- Control methods are discussed in terms of-

- Relevant test results (cited from the literature)

- Parameters affecting the effectiveness of the control method, such as its construction materials, or climate

\section{Comparison With Relevant Documents:}

- This is intermediate in its applicability to Superfund actions between a scientific research report (for example, "Treatment of Contaminated Soils With Aqueous Surfactants" (EPA, 1985)) and a Superfund guidance document (for example, "Mobile Treatment Technologies for Superfund Wastes" (EPA, 1986)). 


\section{Applicability to RCRA Corrective Measures:}

- This will be useful as background data to evaluate potential corrective measures that address VOC emissions at surface impoundments and landfills. 


\section{Guidance Document Name:}

Technical Guidance for Corrective Measures-Determining Appropriate Technology and Response for Air Releases

EPA/530/SW-88/021 (PB88-185269)

\section{Originating Office:}

U.S. EPA, Office of Solid Waste and Emergency Response, Office of Solid Waste

Status: March 1985 (Contractor's Final Report)

Environmental Media Covered: Air

Purpose of the Guidance Document:

- Assists EPA and State personnel in implementing RCRA corrective action provisions by providing a central source of information on air emission control technologies and techniques for hazardous waste treatment, storage, and disposal facilities.

\section{Scope of the Guidance Document:}

- Describes waste management unit decision and operation practices that prevent or control vapor and particulate releases from containerized waste storage, storage tanks, surface impoundments, landfills, land treatment, and waste piles.

- Discusses control technologies used in the industrial/commercial sector.

\section{Technical Approach:}

- Uses flow charts, tables, and narrative descriptions to characterize corrective measures technologies by-

- Facility-specific applicability

- Cost-effectiveness

- Effectiveness in reducing air emissions

- Discussess corrective measures for specific facility types in terms of-

- Major causes for releases

- Control options available

- Advantages/disadvantages of the various control options 


\section{Comparison With Relevant Documents:}

- This is part of a group of documents that addresses releases to air, surface water, ground water, and soil. By itself, this document does not provide the technical detail to choose or implement a corrective action.

\section{Applicability to RCRA Corrective Measures:}

- This provides guidance for the selection of potential corrective measures to address air releases, although this document by itself would not provide adequate technical detail for corrective measures selection or implementation. 


\section{Guidance Document Name:}

Technical Guidance for Corrective Measures-Subsurface Gas EPA/530/SW-88/023 (PB88-185285)

\section{Originating Office:}

U.S. EPA, Office of Solid Waste and Emergency Response, Office of Solid Waste

Status: March 1985 (Contractor's Final Report)

Environmental Media Covered: Subsurface gas

\section{Purpose of the Guidance Document:}

- Assists in the assessment of the potential for subsurface gas generation and migration from these facilities and describes potential corrective measures.

\section{Scope of the Guidance Document:}

- Provides an overview of factors that affect subsurface gas generation and migration.

- Provides methods to identify a subsurface gas release by the presence of specific hazardous waste constituents.

- Describes criteria for emergency situations, investigation methods, and potential remedies.

Technical Approach:

- Discusses regulatory/statutory requirements-

- Concentration limits

- Definition of a release

- Indicator constituents

- Discusses forms of gas generation in terms of biological, chemical, and physical decomposition.

- Discusses barriers affecting gas migration.

- Provides checklists for identifying subsurface gas releases during a preliminary assessment.

- Describes subsurface sampling techniques. 
- Discusses data requirements for the development of models to predict the migration of subsurface gas.

- Discusses procedures for subsurface gas field monitoring.

\section{Comparison With Relevant Documents:}

- This document is unique within the scope of this Compendium.

\section{Applicability to RCRA Corrective Measures:}

- This document has primary applicability to investigation and corrective measure phases; it provides a format for subsurface gas field monitoring and for sampling the volatile organics present in subsurface gas. 


\section{Site Assessment and Health Assessment}

This section reviews and summarizes a total of four site assessment guidance documents. These documents would be most useful for the site investigation and assessment steps that would be conducted prior to a corrective measures study. Several of the documents describe data collection and analysis techniques for assessing the potential for, types of, and degree of hazard that may result from a contaminant release. As these documents are generally more closely related to the RFA/RFI phases of corrective action than to corrective measures implementation, their use in the corrective measures study will be limited. The summaries follow. 


\section{Guidance Document Name:}

Guidance for Conducting Remedial Investigations and Feasibility Studies (RI/FS) Under CERCLA

EPA/540/G-89/004 (PB89-184626)

\section{Originating Office:}

U.S. EPA, Office of Research and Development, Office of Emergency and Remedial Response, Office of Waste Programs Enforcement

Status: October 1988

Environmental Media Covered: Ground water, surface water, air, soil

\section{Purpose of the Guidance Document:}

- Provides technical guidance to Superfund staff, contractors, and potentially responsible parties on how to conduct a remedial investigation and a feasibility study under CERCLA.

- Describes how to characterize the extent of existing contamination and the potential for a release to soils, ground water, surface water, and air from uncontrolled hazardous waste sites on the National Priorities List.

- Describes the interplay of the remedial investigation and feasibility study activities during the development of a response.

\section{Scope of the Guidance Document:}

- Provides guidance on National Contingency Plan requirements that must be met by Regions, their contractors, and potentially responsible parties in conducting CERCLA site investigations.

\section{Technical Approach:}

- Focus on data collection and site characterization to provide the information required for a detailed analysis of alternatives conducted during the feasibility study.

- Initial activities consist of collecting and evaluating existing information on site and waste characteristics, migration pathways, receptors, and potential impacts on public health, welfare, and the environment. 
- A sampling plan is developed to determine the extent of hazardous contamination at the site and to specify field activities required for the remedial investigation. A quality assurance program is required to ensure that proper collection, transport, and validation procedures were used.

- Health and safety activities are used when any type of field work is involved. These activities are designed to protect the investigative team and the general public against chemical hazards, physical injuries, and fire.

- Site characterizations provide data to support decisions to be made in the feasibility study. As such, they encompass a wide variety of waste and site conditions, such as physical and chemical properties of wastes, site engineering, geology, hydrogeology, surface-water conditions, and atmospheric processes. Site characterization activities may include a review of existing data, geologic and hydrogeologic investigations, sampling and analysis of all media, and quantitative numerical modeling to determine the fate and transport of contaminants.

- The remedial investigation guidance does not require that all three levels be completed; the process may terminate at any level provided that sufficient data have been obtained to support, at a minimum, the screening of remedial technologies and alternatives.

- The focus, data needs, and data evaluations conducted at each level of the investigation are described.

\section{Comparison With Relevant Documents:}

- The CERCLA remedial investigation three-level data collection process is similar to the RFI two-step data collection process: Level I under remedial investigation guidance essentially the same as the collection and review of existing information in the RFI; Levels II and III problem quantification and detailed investigation in CERCLA remedial investigations are similar to RFI formulation and implementation of the field investigation step.

- The CERCLA remedial investigation activities focus on all hazardous substances named in CERCLA $\$ 102$ (which include the constituents regulated under RCRA, the Clean Water Act, the Clean Air Act, and others), while the RFI specifically adds constituents listed in 40 CFR Part 261, Appendix VIII.

\section{Applicability to RCRA Corrective Measures:}

- This document provides guidance for data collection and site characterization necessary prior to the study and selection of appropriate corrective measures. 


\section{Guidance Document Name:}

Human Health Evaluation Manual

Volume I-EPA/540/1-89/002 (PB90-155581)

Volume II-EPA/540/1-89/001 (PB90-155599)

\section{Originating Office:}

U.S. EPA, Office of Solid Waste and Emergency Response, Office of Emergency and Remedial Response

Status: Final, 1989

Environmental Media Covered: All potential exposure pathways

\section{Purpose of the Guidance Document:}

- Establishes an institutional framework for public health evaluation at Superfund sites.

- Issues guidance on the development of health-based performance goals for remedial alternatives.

\section{Scope of the Guidance Document:}

- This is to be used during CERCLA remedial investigation and feasibility study activities to meet the requirements of the National Contingency Plan for conducting public health evaluations.

- The procedures in this document are to be used during the feasibility study and at sites where endangerment assessments are conducted pursuant to CERCLA $\S 106$.

\section{Technical Approach:}

- Covers agency rules, policies, and guidelines, as well as an overview of the use of indicator chemicals to assess risk.

- Has procedures conforming with EPA risk assessment guidelines.

- Details the use of public health assessment information in the feasibility study.

- Describes statutory and regulatory authorities for implementing risk assessments.

- Outlines the appropriate methods for the selection of indicator chemicals. 
- Describes methods for estimating exposure point concentrations of indicator chemicals.

- Describes methods for estimating chemical intakes or exposures through the various environmental media.

- Describes the implementation of a toxicity assessment.

- Details the steps involved in risk characterization.

- Describes the development of performance goals and the analysis of risks for remedial alternatives.

\section{Comparison With Relevant Documents:}

- This is designed to supplement a chapter 5 in "Guidance for Conducting Remedial Investigations and Feasibilities Studies Under CERCLA."

- This should be used in tandem with the "Superfund Exposure Assessment Manual."

\section{Applicability to RCRA Corrective Measures:}

- This has useful information on contaminant toxicity and other properties and on health assessment techniques. 


\section{Guidance Document Name:}

Superfund Exposure Assessment Manual

EPA/540/1-88/001 (PB89-135859)

\section{Originating Office:}

U.S. EPA, Office of Solid Waste and Emergency Response, Office of Emergency and Remedial Response

Status: Final, April 1988

Environmental Media Covered: Air, soils, surface water, ground water

\section{Purpose of the Guidance Document:}

- Complements the "Human Health Evaluation Manual" by describing how to develop both quantitative and qualitative exposure information at uncontrolled waste sites to support a public health evaluation during the feasibility study.

- Presents procedures for making an analysis of contaminant release, transport, and fate, along with human population exposure.

\section{Scope of the Guidance Document:}

- This is to be used during the CERCLA remedial investigation and feasibility study activities to meet the requirements of the National Contingency Plan for conducting public health evaluations. It should be used in conjunction with the "Human Health Evaluation Manual" and "Endangerment Assessment Handbook."

- The procedures in this document are meant to be applied during the feasibility study to analyze the baseline, "no action" alternative.

\section{Technical Approach:}

- Presents a framework for conducting an exposure assessment based on the following steps-

- Contaminant release analysis-medium-specific analysis of mass loadings of each target chemical to specific environmental media

- Environmental fate analysis-description of the extent and magnitude of environmental contamination, which allows user to predict human population contact with chemicals from the site

- Exposed populations analysis-identification, enumeration, and characterization of those population segments likely to be exposed 
- Integrated exposure analysis-individual exposure estimates for each exposure route (that is, inhalation, ingestion of drinking water and/or food, dermal contact) developed for released chemicals

- Provides mathematical equations for predicting emissions rates from wastes to air, soils, surface water, and ground water. Also describes appropriate computer models for estimating emissions rates.

- Describes mathematical and computer modeling approaches to determining the environmental fate of contaminants in air, surface water, ground water, and biotic fate pathways.

\section{Comparison With Relevant Documents:}

- This document is designed to provide quantitative information on exposures at hazardous waste sites needed to conduct a Superfund public health evaluation as required in the National Contingency Plan. Accordingly, the document is a more detailed and comprehensive document on exposure assessments than the "RCRA Exposure Information Assessment" guidance document.

- This covers fundamentally the same media and types of release considered in the "RCRA Exposure Information Assessment" guidance document.

\section{Applicability to RCRA Corrective Measures:}

- This would be most useful in the facility assessment and investigation steps that would be conducted prior to a corrective measures study. 


\section{Guidance Document Name:}

The Endangerment Assessment Handbook

OSWER Directive No. 9850.1 (PB91-139683)

\section{Originating Office:}

U.S. EPA, Office of Solid Waste and Emergency Response, Office of Waste Programs Enforcement

Status: Final, November 1985

Environmental Media Covered: All

Purpose of the Guidance Document:

- Provides technical and procedural guidelines for developing and conducting endangerment assessments to support administrative and judicial enforcement actions under CERCLA §106(a) and RCRA §7003. The endangerment assessment process should be initiated as soon as a site is identified as an enforcement site and administrative or judicial actions are considered.

- Describes how to initiate the endangerment assessment process once a site has been identified as a CERCLA $\$ 106$ or RCRA $\$ 7003$ enforcement site, which may take place at any point in the overall corrective action process after site identification.

\section{Scope of the Guidance Document:}

- Assists EPA Regional, State, and contractor personnel in conducting and evaluating the endangerment assessment and in preparing necessary documentation that will justify the enforcement needs of each case.

- Provides the basis for the findings of fact in administrative orders, consent degrees, and complaints.

\section{Technical Approach:}

- Presents and discusses the content and recommended format for the endangerment assessment document-

- Contaminant identification-screens the information available on types and concentrations of hazardous substances or wastes present at the site and identifies those contaminants of concern based on their intrinsic toxicological properties, concentration and distribution, or their potential release to critical exposure routes and subsequent migration into the surrounding environment. If sufficient information on contaminants at the site is unavailable, sampling and analysis for suspected contaminants and locations should be initiated. 
- Exposure assessment-identifies the type and concentration of each contaminant of concern and determines the amount of each contaminant released to each environmental medium. Identifies the potential exposure (transport) routes associated with each contaminant. Identifies and analyzes populations, including human populations, fish, and wildlife populations, that may be at risk. Determines the exposure levels based on frequency, mode, and magnitude of exposure to a given contaminant.

- Toxicity assessment-evaluates adverse effects of each contaminant, doses employed, routes of administration (oral, dermal, inhalation), and quality of test data to determine the toxicity profile of the contaminant. Next, a doseresponse relationship is determined that estimates a quantitative risk from exposure to the contaminant of concern.

- Risk characterization-attains a risk assessment by integrating the information developed during the exposure and toxicity assessments to yield a qualitative value of risk. The final risk assessment should include a summary of the uncertainties of each component per risk, the risk associated with various subpopulations, assumptions used in calculating the risks, the relation between risks, and an acceptable contaminant concentration level.

\section{Comparison With Relevant Documents:}

- This document was prepared before either the "Human Health Evaluation Manual" or the "Superfund Endangerment Assessment Manual," although this document references the "Human Health Evaluation Manual." This was prepared to complement the information that was to be provided in those documents. Accordingly, both the "Human Health Evaluation Manual" and the "Superfund Endangerment Assessment Manual" reference their applicability to the conduct of endangerment assessments and should be considered consistent with each other, although not identical.

- Because this is designed to provide information sufficient to support an administrative order under CERCLA $\$ 106$ or RCRA \$7003, the information collection described is more detailed than that required under the "RCRA Exposure Information Assessment" guidance document. Information collected using the exposure information assessment guidance must only demonstrate that a potential problem exists that should be investigated further, but it cannot support an enforcement action, which may require more quantitative data.

- The procedures described in this document are similar to those described in the CERCLA and feasibility study documents; in those cases where an enforcement action is initiated after completion of a remedial investigation or feasibility study, the requirements of this document may be met by the "Site Characterization" and "Analysis of No-Action Alternative" sections of the remedial investigation and feasibility study document. 


\section{Applicability to RCRA Corrective Measures:}

- This would be most useful in the site assessment and investigation and assessment steps that would be conducted prior to a corrective measures study. 


\section{Construction Techniques/Procedures}

This section includes a total of three documents that specify construction techniques and field operating procedures. The following summaries include brief assessments of the applicability of the documents to RCRA program corrective measures implementation. 


\section{Guidance Document Name:}

Field Standard Operating Procedures (FSOP)

\#6-Control No. 9285.2-04 (PB91-213827)

\#7-Control No. 9285.2-02 (PB91-213850)

\#8-Control No. 9285.2-03 (PB91-213843)

\#9-Control No. 9285.2-05 (PB91-213835)

\section{Originating Office:}

U.S. EPA, Office of Solid Waste and Emergency Response, Office of Emergency and Remedial Response

Status: Final, January (\#7 and \#8) and April (\#6 and \#9) 1985

Environmental Media Covered: Soil and air

\section{Purpose of the Guidance Document:}

- Outlines procedures that should be followed to minimize the risk of exposure to hazardous substances.

- Each of the four FSOP's reviewed outlines the operating procedures for specific components of the remedial action program, including-

- Work zones (\#6)

- Decontamination of response personnel (\#7)

- Air surveillance (\#8)

- Preparation of a site safety plan (\#9)

\section{Scope of the Guidance Document:}

- Applies to emergency response team members, remedial action team members, and personnel who plan for emergency responses or remedial actions.

\section{Technical Approach:}

- Each FSOP addresses a different aspect of personnel protection at contaminated sites. Each FSOP is divided into different sections. The sections generally provide the following-

- A general description of the given protective measures and why and when they are necessary

- A description of the different levels of protection available within the given protective measure (for example, the types of incidents encountered when performing air surveillance or the degree of stringency when choosing personal protective equipment) 
- Factors and criteria to consider when choosing a plan of action (for example, how to select the locations of and the stringency of procedures to follow in different work zones)-

- Descriptions of techniques that can or should be employed

- Step-by-step instructions (for example, 13 steps in putting on level A protective equipment)

- Checklists (for example, minimum data required for safety both before and after a response)

\section{Comparison With Relevant Documents:}

- Most of these FSOP's were developed from the November 1984 "Standard Operating Safety Guides."

- These FSOP's are to be used by field technicians, as opposed to administrative, managerial, and quality assurance officers. "A Compendium of Superfund Field Operations" fulfills the information needs of the managerial personnel.

\section{Applicability to RCRA Corrective Measures:}

- These documents will be useful in guiding field-related activities and for ensuring that OSHA standards are met during corrective measures implementation. 


\section{Guidance Document Name:}

RCRA Facility Assessment (RFA) Guidance

EPA/530/SW-86/053 (PB87-107769)

\section{Originating Office:}

U.S. EPA, Office of Solid Waste and Emergency Response, Office of Solid Waste

Status: Final, October 1986

Environmental Media Covered:

Ground water, surface water, air, subsurface gas, soils

\section{Purpose of the Guidance Document:}

- Provides technical guidance to EPA and State personnel on conducting the RCRA Facility Assessment (RFA) at solid waste management units.

\section{Scope of the Guidance Document:}

- Presents procedures and criteria to identify releases or potential releases from solid waste management units during the RFA. The document addresses the following-

- Conducting a preliminary review

- Conducting a visual site inspection

- Determining the need for further action during the RFA

- Media assessment

\section{Technical Approach:}

- The RFA requires collecting extensive data on solid waste management units, including-

- Unit characteristics

- Waste characteristics

- Pollutant migration pathways

- Evidence of release

- Exposure potential

- Each chapter in this document describes the factors in each of the above five categories that investigators should examine for identifying releases or potential releases for each of the media of concern. 


\section{Comparison With Relevant Documents:}

- This is the sole guidance document in this Compendium that specifically addresses the initial assessment of solid waste management units to determine whether there are releases or potential releases that warrant further investigation under the RCRA Facility Investigation (RFI) process.

\section{Applicability to RCRA Corrective Measures:}

- This provides guidance for identifying releases or potential releases that may require a corrective measures study or implementation. The document, however, does not address corrective measures technologies. 


\section{Guidance Document Name:}

RCRA Facility Investigation (RFI) Guidance

EPA/530/SW-89/031 (PB89-200299)

\section{Originating Office:}

U.S. EPA, Office of Solid Waste and Emergency Response, Office of Solid Waste

Status: Final, May 1989

Environmental Media Covered:

Ground water, surface water, air, subsurface gas, soils

\section{Purpose of the Guidance Document:}

- Provides owners or operators with guidance on conducting a RCRA Facility Investigation (RFI), based on release determinations made by the regulatory agency (generally resulting from the RFA).

\section{Scope of the Guidance Document:}

- Presents procedures and criteria to characterize releases from solid waste management units and hazardous waste management units during the RFI. The guidance is divided into 15 sections and presented in 4 volumes. Volume I presents the procedures and rationale that should be used to develop a work plan for conducting the investigation, a general strategy or release investigations, and the means by which the data collected during the RFI may be interpreted by the regulatory agency. Volumes II (soil, ground water, and subsurface gas) and III (air and surface water) describe media-specific methods for conducting the RFI. Volume IV presents a number of case study illustrations on various aspects of the RFI process.

\section{Technical Approach:}

- The guidance is designed to provide the owner or operator with a logical progression of tasks to be following in investigating a release. Generally, these tasks will consist of-

- Gathering information on the source of the release to the environment (for example, gathering information on the unit and the waste in the unit)

- Gathering physical information on the environment surrounding the unit that will affect the migration and fate of the release (for example, ground-water flow direction, average wind speeds, soil types) 
- Using the above information along with any existing monitoring or modeling information, developing a conceptual model of the release, and planning and conducting a monitoring program to define the nature and extent of the release

- Comparing the concentrations of hazardous constituents identified during the release characterization against health and environmental criteria (chemical concentrations) to determine whether interim corrective measures or a corrective measures study may be needed

\section{Comparison With Relevant Documents:}

- This is the sole guidance document in this Compendium that specifically addresses the characterization of the nature and extent of releases from solid waste management units and provides health and environmental criteria to which these data are compared in determining the need for interim correction measures or a corrective measures study.

\section{Applicability to RCRA Corrective Measures:}

- This provides guidance for characterizing release from solid waste management units that may require a corrective measures study or implementation. This document discusses types of interim corrective measures; however, it does not address corrective measures technologies. 


\section{Costing Techniques}

This section includes a total of two documents on costing techniques. These document provide guidance on how to manage, develop, and evaluate costs associated with the remediation of contaminated sites. The following summaries include brief assessments of the applicability of the documents to RCRA program corrective measures implementation. 


\section{Guidance Document Name:}

Remedial Action Costing Procedures Manual

EPA/600/8-87/049 (PB88-113691)

\section{Originating Office:}

U.S. EPA, Office of Solid Waste and Emergency Response, Office of Emergency and Remedial Response

Status: Final, October 1987

\section{Environmental Media Covered:}

Only general costing procedures are discussed. No specific environmental media are identified.

\section{Purpose of the Guidance Document:}

- Provides specific procedures for the cost estimating and economic analysis steps required for preparing engineering cost estimates for selecting remedial action alternatives in response to CERCLA and the National Contingency Plan.

- For use in conjunction with EPA's guidance on feasibility studies under CERCLA.

\section{Scope of the Guidance Document:}

- Presents procedures and provides worksheets to accomplish cost analysis required for various remedial action planning phases.

\section{Technical Approach:}

- Divides remedial action costing into three phases-

- Initial site response assessment plan phase

- Alternate development and cost screening phase

- Cost estimation phase for feasibility studies

\section{Comparison With Relevant Documents:}

- This provides a more comprehensive approach to cost management than the "Removal Cost Management Manual," which addresses only costing procedures at CERCLA emergency response actions (removals). 


\section{Applicability to RCRA Corrective Measures:}

- This provides project managers and decisionmakers in government and industry with procedures for developing and evaluating cost estimates for alternative remedial responses to releases of hazardous substances. 


\section{Guidance Document Name:}

Removal Cost Management Manual

OSWER Directive No. 9360.0-028 (PB90-153891)

\section{Originating Office:}

U.S. EPA, Office of Solid Waste and Emergency Response, Office of Emergency and Remedial Response

Status: Final, January 1985

Environmental Media Covered: None

Purpose of the Guidance Document:

- Provide comprehensive cost management procedures for use by EPA at emergency response actions (removals) authorized under CERCLA.

- For use by the on-scene coordinator.

Scope of the Guidance Document:

- Outlines a comprehensive cost management system for CERCLA emergency response actions.

Technical Approach:

- Discusses cost projection, control, recovery, and documentation.

\section{Comparison With Relevant Documents:}

- Unlike the "Remedial Action Costing Procedures Manual," this document addresses only costing procedures at CERCLA emergency response actions (removals).

\section{Applicability to RCRA Corrective Measures:}

- This provides guidance on how to manage costs associated with the remediation of contaminated sites. 


\section{Quality Assurance/Quality Control Guidance Documents}

This section contains a total of three quality assurance/quality control guidance documents. These documents provide guidance on the quality assurance/quality control of field operations, data collection, and laboratories contracted to provide analytical services. The following summaries include brief assessments of the applicability of the documents to RCRA program corrective measures implementation. 


\section{Guidance Document Name:}

A Compendium of Superfund Field Operations EPA/540/P-87/001 (PB88-181557)

\section{Originating Office:}

U.S. EPA, Office of Solid Waste and Emergency Response, Office of Emergency and Remedial Response

Status: Final, March 1987

Environmental Media Covered: Soils, ground water, surface water, air

Purpose of the Guidance Document:

- Provides remedial project managers, quality assurance officers, and States with a consolidated reference of all remedial project manager field procedures, with the exception of site safety issues and personal protection requirements.

- Promotes consistent field procedures among all ten EPA Regions.

- Compiled from procedures that were used successfully in executing EPA work assignments nationwide.

\section{Scope of the Guidance Document:}

- Provides a systematic comprehensive approach for conducting field activities under Superfund.

- Covers all aspects of field activities, including the development of field operation plans, site activities, sampling and analysis, and documentation.

\section{Technical Approach:}

- Provides detail on the purpose, scope, procedures, applicability, and responsibilities associated with all aspects of field operations, with the exception of site safety issues, personal protection, and sampling program design. Includes the following topics-

- Documentation of field activities, sampling and analysis, quality control, and corrective action

- Field activity procedures 
- Sampling and analysis-

- Handling and control

- Laboratory procedures and interface

- Interpretation of the results of analyses

- Gathering of proper samples

- Assesses environmental impacts.

- Provides quality assurance and document control auditing.

\section{Comparison With Relevant Documents:}

- This applies to current EPA Regional standards and quality assurance requirements. Other documents appropriate to any aspect of field activities (for example, most recent directives, memoranda, guidance documents, and approved quality assurance plans) should be consulted simultaneously.

\section{Applicability to RCRA Corrective Measures:}

- Although this document identifies the procedural requirements of the quality assurance program for Superfund related to field operations work, it will still have applicability to the RCRA program in that major program components are identified and key interfaces detailed. This document should be useful in developing measures for field operations quality assurance programs. 


\section{Guidance Document Name:}

Data Quality Objectives for Remedial Response Activities, Volumes 1 and 2 OSWER Directive No. 9355.0-07B (PB90-272634)

\section{Originating Office:}

U.S. EPA, Office of Solid Waste and Emergency Response, Office of Emergency and Remedial Response, Office of Waste Programs Enforcement

Status: Final, March 1987

Environmental Media Covered: Soil, ground water

\section{Purpose of the Guidance Document:}

- Provides assistance in developing site-specific data quality objectives for Superfund remedial investigation/feasibility study activities.

\section{Scope of the Guidance Document:}

- Data quality objectives are written plans for ensuring that environmental data collected during remedial investigation/feasibility study activities are of known and documented quality. Data quality objectives are developed prior to data collection and are linked to sampling and analysis plans.

- Provides guidance and examples on the process by which data quality objectives are developed, the individuals responsible for preparing data quality objectives, the relationship of data quality objective guidance to other guidance, and the timing for data quality objective development.

\section{Technical Approach:}

- Data quality objectives are developed in three stages-

- Identify decision types

- Identify data uses/needs

- Design data collection program

- Provides specific guidelines and procedures for evaluating available information, developing conceptual models, specifying objectives, identifying data needs, and developing data collection plans.

- Specifies statistical procedures, including sampling patterns, sample size, and uncertainty of estimates. 


\section{Comparison With Relevant Documents:}

- The guidance is similar to "Test Methods for Evaluating Solid Waste" (SW-846) in its review of statistical sampling considerations. However, it is less detailed in describing the analytical techniques and tools used in sampling waste sites.

\section{Applicability to RCRA Corrective Measures:}

- This provides guidance for designing a data collection program for the assessment and investigation activities that would precede a corrective measures study. 


\section{Guidance Document Name:}

User's Guide to the Contract Laboratory Program

EPA/540/P-91/002 (PB91-921278)

\section{Originating Office:}

U.S. EPA, Office of Solid Waste and Emergency Response, Office of Emergency and Remedial Response

Status: Final, January 1991

Environmental Media Covered: Soil/sediment, water

\section{Purpose of the Guidance Document:}

- Provides a description of the Superfund Contract Laboratory Program structure.

- Establishes protocol for standardizing procedural approaches to contracting analytic services.

\section{Scope of the Guidance Document:}

- For use by remedial program managers, remedial investigation/feasibility study contractors, and potentially responsible parties throughout the data collection and analysis process of the CERCLA remedial investigation.

- For use by all handlers of samples and data to ensure the reliability and integrity of the data.

\section{Technical Approach:}

- Covers five separate analytic programs-

- Organic Routine Analytical Services (RAS)

- Inorganic RAS

- Dioxin RAS

- High Hazard Sample Preparation RAS

- Special Analytical Services

- Describes methods for sample analysis scheduling and coordination with other program components.

- Provides guidance on program quality assurance and quality control. 
- The Contract Laboratory Program provides a menu of RAS services that are correlated to various program components, including-

- Sample matrices

- Compounds identified and quantified

- Deliverables

- Analytic procedures

- Quality assurance/quality control

- The Contract Laboratory Program requires workers' initiation on standard operating procedures, including-

- Chain of custody controls between various program offices

- Health and safety measures

- Analytical protocol

- Sample documentation

- Problem resolution

- Auxiliary support services are described, including-

- Sample bottle repository services

- Ordering procedures

- Shipment information

- Enforcement interaction with the Contract Laboratory Program includes-

- Document controls

- Evidence audits

- Cost recovery substantiation procedures are described.

- Quality assurance includes-

- Laboratory selection screening

- Laboratory performance

- Evaluations

- Sample data evaluations

\section{Comparison With Relevant Documents:}

- This provides a systematic, overall program management response to analytic services contracting in contrast to SW-846. The later document covers laboratory protocol and quality assurance/quality control; however, it does not provide a systematic program structure for implementing RCRA analytic services.

\section{Applicability to RCRA Corrective Measures:}

- This provides guidance to contractors performing remedial investigations and assessments on procedural approaches to contracting analytical services to ensure the =eliability and integrity of the data. 


\section{Program Guidance Documents}

A key RCRA program guidance document has been summarized in this section. This document, the "RCRA Corrective Action Plan," provides the basic framework for the overall program, which can be supplemented by additional RCRA and CERCLA program guidance documents. A second document in this section applies directly to the RCRA Corrective Action program.

This section also reviews and summarizes a total of 12 CERCLA program guidance documents. In general, this group of documents provides comprehensive program and project management guidance on implementing the remedial investigation/ feasibility study process within the statutory and regulatory context of CERCLA. The majority of these documents will be of marginal use in the development of a RCRA corrective measures study and its implementation. There are, however, some useful approaches to format and style in selected documents that may be of use to RCRA corrective measures implementation. 


\section{Guidance Document Name:}

RCRA Corrective Action Plan

OSWER Directive No. 9902.3 (PB91-139873)

\section{Originating Office:}

U.S. EPA, Office of Solid Waste and Emergency Response, Office of Waste Programs Enforcement

Status: Final, November 1986

Environmental Media Covered: Ground water, soils, surface water, air

\section{Purpose of the Guidance Document:}

- Assists Regions and States in the development of corrective action orders (§3008(h)) February 12, 1992 and corrective action requirements in permit applications and permits.

\section{Scope of the Guidance Document:}

- Provides a technical framework for Regional and State personnel in the development of a site-specific schedule of compliance to be included in a permit or a compliance schedule in a corrective action order; includes requirements for RCRA facility investigations, corrective measures studies, and work plans for corrective measures implementation.

\section{Technical Approach:}

- Provides a detailed discussion of the information to be provided for each of the following tasks-

- RCRA Facility Investigation

Task I: Description of Current Conditions

Task II: Pre-investigation Evaluation of Corrective Measure Technologies

Task III: RFI Workplan Requirements

Task IV: Facility Investigation

Task V: Investigation Analysis

Task VI: Laboratory and Bench-Scale Studies

Task VII: Reports 
- Corrective Measure Study

Task VIII: Identification and Development of the Corrective Measure Alternative or Alternatives

Task IX: Evaluation of the Corrective Measure Alternative or Alternatives

Task X: Justification and Recommendation of the Corrective Measure or Measures

Task XI: Reports

- Corrective Measure Implementation

Task XII: Corrective Measure Implementation Program Plan

Task XIII: Corrective Measure Design

Task XIV: Corrective Measure Construction

Task XV: Reports

- The three-step approach outlined above is intended to standardize the data collection process and provide for key decision milestones throughout the Corrective Action process. Each step provides for the collection of increasingly detailed data for the characterization of site contamination.

- Major considerations in planning data quality control and verification programs can be developed using the corrective action plan framework.

- The process is to be employed whether site-specific Corrective Action is required as a permit condition or whether it is required as a result of enforcement action.

\section{Comparison with Relevant Documents:}

- Technical guidance on media-specific technologies identified in this summary may be used to supplement the outline given in the corrective action plan.

- Specific costing considerations of RCRA corrective measures implementation should be taken from the corrective action plan rather than OERR's "Remedial Action Costing Procedures Manual." The OERR document includes fundbalancing criteria that are not relevant to the RCRA Corrective Action program.

\section{Applicability to RCRA Corrective Measures:}

- This document is a key resource document for Regional and State permit writers guiding corrective action at permitted facilities. It should be used to guide completeness checks of submittals made by owner/operators and for developing the $\$ 3008(\mathrm{~h})$ order and permit schedule of compliance language. 


\section{Guidance Document Name:}

Stabilization Technologies for RCRA Corrective Actions $\mathrm{EPA} / 625 / 4-91 / 029$

\section{Originating Office:}

U.S. EPA, Office of Research and Development, Center for Environmental Research Information

Status: Final, August 1991

Environmental Media Covered: Soil and water

\section{Purpose of the Guidance Document:}

- Provides guidance on identifying the types of environmental settings that should be the focus of stabilization actions.

- Provides technical approaches to accelerate data gathering in support of decisions on appropriate stabilization measures and on phasing the RCRA Facility Investigation (RFI) process to gather the necessary data to make timely decisions within the framework of the existing corrective action program.

\section{Scope of the Guidance Document:}

- Addresses the overall goal of the RCRA corrective action stabilization initiative: to, as soon as possible, control or abate imminent threats to human health and the environment from release from RCRA facilities and to prevent or minimize the further spread of contamination with long-term remedies are pursued.

- Provides the technical decision guidance for implementing a number of stabilization technologies.

\section{Technical Approach:}

- Addresses technologies for containment, soils treatment, and water treatment.

\section{Comparison With Relevant Documents:}

- This document address many technologies that are found in other EPA documents, and it is the only EPA document that addresses specific technologies for meeting the RCRA corrective action stabilization initiative. 


\section{Guidance Document Name:}

National Contingency Plan (NCP), 40 CFR Part 300

\section{Originating Office:}

U.S. EPA, Office of Solid Waste and Emergency Response, Office of Emergency and Remedial Response

Status: Final, February 12, 1985 (50 FR 5862)

\section{Environmental Media Covered:}

Ground water, surface water, air, soils, and sediments

\section{Purpose of the Guidance Document:}

- Provides the regulatory framework for implementing CERCLA. In particular, Subpart F-Hazardous Substances Response-establishes methods and criteria for determining the extent and nature of a CERCLA-authorized response.

\section{Scope of the Guidance Document:}

- Subpart F of the NCP-

Provides the general requirements for all phases of a CERCLA hazardous substance response

- Outlines the responsibilities of Federal and State officials in a CERCLA hazardous substance response

- Outlines the minimum requirements for conducting a remedial investigation and a feasibility study under CERCLA

Technical Approach:

- 40 CFR 300.68-Remedial action-

- Mandates a remedial investigation/feasibility study to determine the nature and extent of the threat presented by a release and to evaluate proposed remedies

- Requires the development of remedial alternatives as part of the feasibility study

- Requires an analysis of these alternatives on the basis of-

- Cost

- Acceptability of engineering practices

- Effectiveness

- Selects a remedy that attains or exceeds Federal public health and environmental requirements 
- 40 CFR 300.70-Methods of remedying releases-

- Lists engineering methods for onsite actions, including-

- Air emissions controls

- Surface-water controls

- Ground-water controls

- Remedies for contaminated water and sewer lines

- Lists technologies for-

- Gaseous emissions treatment

- Direct waste treatment

- Treatment of contaminated soils and sediments

\section{Comparison With Relevant Documents:}

- This provides the regulatory basis for many EPA guidance documents, including the "Guidance Document for Cleanup of Surface Tank and Drum Sites" (EPA, 1985) and "Mobile Treatment Technologies for Superfund Wastes" (EPA, 1986).

\section{Applicability to RCRA Corrective Measures:}

- This document provides background guidance on data requirements for conducting remedial actions.

- It also describes technical and cost considerations of technologies used in assessment studies. 
Guidance Document Name:

Superfund Remedial Design and Remedial Action Guidance EPA/9355.0-04A (PB88-107529)

\section{Originating Office:}

U.S. EPA, Office of Solid Waste and Emergency Response, Office of Emergency and Remedial Response

Status: Final, February 1985

\section{Environmental Media Covered:}

Does not specifically address any media; focuses on administrative requirements.

\section{Purpose of the Guidance Document:}

- To assist agencies and parties who plan, administer, and manage remedial design and remedial action at Superfund sites. Pertains to both fund-financed remedial design/action (that is, Federal- and State-lead) and responsible party remedial design/action, and provides personnel guidance to be followed to ensure that remedial design/action is performed properly, consistently, and expeditiously.

\section{Scope of the Guidance Document:}

- Outlines administrative requirements based on the general sequence of events that occurs prior to, during, and after remedial design/action at a Superfund site. Pertains to both fund-financed and responsible party projects.

\section{Technical Approach:}

- Defines the administrative requirements, contents, and elements in the remedial design/action processes. For remedial design, that process includes-

- Activities involved in selecting an architect/engineering (A/E) firm

- Development of the remedial design and distribution of planning information to the lead design party

- Development of a statement of work for the A/E firm retained to accomplish the remedial design

- Review and approval of the A/E firm's final plans and specifications

- Identification of applicable permits, permit approvals, and site access agreements

- Revision of the community-relating plan based on the needs of the community during the design and construction activities

- Development of cost estimates for construction 
- The process for the initiation of remedial action includes the following- Selection of the contractor for the remedial action

- Monitoring and oversight of construction activities and needed records and reports to be used in the final certification of the remedial action

- Final inspection and closeout activities after completion of the remedial action

\section{Comparison With Relevant Documents:}

- As outlined above, the remedial design/action guidance provides the administrative and procedural requirements for remedial design/action, as opposed to other documents that highlight the technical aspects of these activities.

\section{Applicability to RCRA Corrective Measures:}

- This may be helpful to the extent that administrative requirements for remedial design/action at Superfund sites coincide with administrative requirements for remedial design/action at RCRA sites. 


\section{Guidance Document Name:}

Community Relations in Superfund: A Handbook (Interim Guidance) EPA/540/G-88/002 (PB89-180830)

\section{Originating Office:}

U.S. EPA, Office of Solid Waste and Emergency Response, Office of Emergency and Remedial Response

Status: Draft, June 1988

Environmental Media Covered: No specific environmental media addressed

\section{Purpose of the Guidance Document:}

- Provides policy requirements for coordinating community relations activities at Superfund sites.

- Provides additional techniques and guidance that can be used to enhance the basic requirements for community relations.

- Describes the overall objectives of the Superfund community relations program.

- Gives citizens the opportunity to comment on and provide input to technical decisions.

- Informs the public of planned or ongoing actions.

- Focuses and resolves conflict.

\section{Scope of the Guidance Document:}

- Describes the various requirements for conducting community relations activities during removal actions, enforcement actions, and remedial response actions and for the addition and deletion of sites from the National Priorities List.

- Describes the two critical steps in planning a community relations program for a Superfund remedial action-

- Conducting community interviews

- Developing a site-specific community relations plan

- Provides a list of all key EPA Headquarters and Regional contacts for the Superfund community relations program. 


\section{Technical Approach:}

- Specifically addresses activities to be conducted during CERCLA corrective actions. "Guidance on Public Involvement in the RCRA Permitting Program" does not currently address specific activities related to RCRA corrective actions.

- Responds to a specific mandate in the National Contingency Plan for conducting community relations not present in RCRA $\$ 3004(u)$ and addresses many specific requirements for public involvement.

\section{Comparison With Relevant Documents:}

- This provides detailed guidelines on CERCLA community relations programs analogous to the public participation guidelines given in OSWER 9500.00-1A, "Guidance on Public Involvement in the RCRA Permitting Program."

\section{Applicability to RCRA Corrective Measures:}

- This may be helpful in formulating a community relations program at a RCRA site. 


\section{Guidance Document Name:}

Superfund Federal-Lead Remedial Project Management Handbook EPA/540/G-87/001 (PB87-183133)

\section{Originating Office:}

U.S. EPA, Office of Solid Waste and Emergency Response, Office of Emergency and Remedial Response

Status: Final, December 1986

Environmental Media Covered: Process affecting all environmental media

\section{Purpose of the Guidance Document:}

- This document serves three general purposes-

- Presents various actions and deliverables that comprise the Federal-lead remedial project, and defines the roles and responsibilities of the remedial project manager

- Identifies resources available to the remedial project manager for supporting the remedial project management function

- Provides fundamental concepts of project management to aid the remedial project manager in planning, monitoring, controlling, and directing projects

\section{Scope of the Guidance Document:}

- Provides basic project management concepts regarding project planning, monitoring, and control and the directing, coordinating, and communicating of project objectives that are to be applied during the CERCLA feasibility study process.

- Discusses initial project planning and startup activities and describes the remedial project manager's role in ensuring that the remedial investigation/feasibility study work is conducted in accordance with project plans.

\section{Technical Approach:}

- Illustrates the process for implementing Federal-lead remedial action by use of a process flow chart with supporting narrative.

- Describes management and control techniques for ensuring project implementation in accordance with the project plan (for example, use of the Gantt milestone chart).

- Illustrates the functional roles of EPA and contractors in implementing remedial investigations and feasibility studies. 
- Describes in detail the various steps involved in startup, implementation, and closeout.

- Describes the role of the record of decision in documenting the decision-making process. Provides a model record of decision.

Comparison With Relevant Documents:

- This is similar in format and design to the "Superfund State-Lead Remedial Project Management Handbook."

Applicability to RCRA Corrective Measures:

- This has no direct applicability to the RCRA corrective measures process. 


\section{Guidance Document Name:}

Superfund State-Lead Remedial Project Management Handbook EPA/540/G-87/002 (PB87-183141)

\section{Originating Office:}

U.S. EPA, Office of Solid Waste and Emergency Response, Office of Emergency and Remedial Response

Status: Final, December 1986

Environmental Media Covered: Process affecting all environmental media

\section{Purpose of the Guidance Document:}

- This document serves three general purposes-

- Presents various actions and deliverables that comprise a State-lead remedial project, and defines the roles and responsibilities of the remedial project manager

- Identifies resources available to the remedial project manager for supporting the remedial project management function

- Provides fundamental concepts of project management to aid the remedial project manager in planning, monitoring, controlling, and directing projects

\section{Scope of the Guidance Document:}

- Provides basic project management concepts regarding project planning, monitoring, and control and the directing, coordinating, and communicating of project objectives that are to be applied during the CERCLA feasibility study process.

- Discusses initial project planning and startup activities and describes the remedial project manager's role in ensuring that the remedial investigation/feasibility study work is conducted in accordance with project plans.

\section{Technical Approach:}

- Illustrates the process for implementing Federal-lead remedial action by use of a process flow chart. Describes the interrelationships of the remedial project manager with the various institutional entities, contractors, and potentially responsible parties.

- Describes management and control techniques for ensuring project implementation in accordance with the project plan (for example, use of the Gantt milestone chart). 
- Illustrates the functional roles of EPA, States, and contractors in implementing remedial investigations and feasibility studies.

- Inventories types of cooperative agreements available between the States and EPA.

- Describes the role of the record of decision in documenting the decision-making process. Provides a model record of decision.

Comparison With Relevant Documents:

- This is similar in format and design to the "Superfund Federal-Lead Remedial Project Management Handbook."

Applicability to RCRA Corrective Measures:

- This has no direct applicability to the RCRA corrective measures process. 


\section{Guidance Document Name:}

State and Local Involement in the Superfund Program

EPA/9375.5-01/FS (PB90-273939)

\section{Originating Office:}

U.S. EPA, Office of Solid Waste and Emergency Response, Office of Emergency and Remedial Response

Status: Final, 1989

\section{Environmental Media Covered:}

Procedural guidance applicable to program management

\section{Purpose of the Guidance Document:}

- Provides an overview of hazardous waste laws, the Superfund process, and future directions of the Superfund program. National Contingency Plan.

- Describes ways that State and Local governments can get involved in the sSuperfund program:mechanisms for assuring State and Local involvement: and the roles of political subdivisions, Indian Tribes, and local governments.

\section{Scope of the Guidance Document:}

- State participation in the Superfund remedial program is to be used during the CERCLA remedial investigation/feasibility study activities. Cooperative agreements may be initiated prior to remedial investigation/feasibility study work; however, they should be fully enforced during the remedial investigation/ feasibility study process.

\section{Technical Approach:}

- Includes description of cooperative agreements, Superfund State contracts, and credit claims.

- Discusses management issues, such as cost-sharing, offsite treatment, storage, and disposal.

- Describes intergovernmental review procedures.

- Inventories types of State assurances available under remedial response agreements. 
- Describes the development of cooperative agreement application forms and provisions.

- Describes the interface with the Federal procurement system.

- For EPA-lead remedial planning agreements, describes EPA and State responsibilities.

- Describes cost-sharing arrangements under Superfund State contracts.

- Describes the execution and administration of the remedial agreement and agreement modifications.

\section{Comparison With Relevant Documents:}

- This should be used with the "Superfund Federal-Lead Remedial Project Management Handbook" and the "Superfund State-Lead Remedial Project Management Handbook."

\section{Applicability to RCRA Corrective Measures:}

- This has no direct applicability to the RCRA corrective measures process. 


\section{Guidance Document Name:}

Policy on Floodplains and Wetlands Assessments for CERCLA Actions Control No. 9280.0-02 (PB91-921329)

\section{Originating Office:}

U.S. EPA, Office of Solid Waste and Emergency Response, Office of Emergency and Remedial Response

Status: Final, August 1985

Environmental Media Covered: Surface water, ground water

\section{Purpose of the Guidance Document:}

- Sets forth Agency policy and guidance for carrying out the provisions of Executive Order 11988 (Floodplain Management) and Executive Order 11990 (Protection of Wetlands), as described in Appendix A of 40 CFR Part 6.

\section{Scope of the Guidance Document:}

- Discusses situations that require preparation of a floodplains or wetlands assessment and the factors that should be considered in preparing an assessment for response actions undertaken pursuant to $\$ 104$ or 106 of CERCLA.

\section{Technical Approach:}

- Discusses the following-

- Removal actions

- Floodplains/wetlands assessment

- Opportunity for citizen comment

- Remedial Actions

- Consideration of environmental issues

- Documentation of decision

\section{Comparison With Relevant Documents:}

- This document is unique in scope.

\section{Applicability to RCRA Corrective Measures:}

- This enunciates EPA's policy to encourage the pursuit of remedies that attain or exceed applicable and relevant standards of other Federal environmental laws that address floodplains and wetlands. 


\section{Guidance Document Name:}

Interim Guidance on Potentially Responsible Party Participation in Remedial Investigations and Feasibility Studies

OSWER Directive No. 9835.1A (PB91-139337)

Revisions to the Interim Guidance on PRP Participation in Remedial Investigations and Feasibility Studies

OSWER Directive No. 9835.2A (PB91-139352)

\section{Originating Office:}

U.S. EPA, Office of Solid Waste and Emergency Response, Office of Waste Program Enforcement

Status: Final, May 1988 and February 1989

\section{Environmental Media Covered: None}

\section{Purpose of the Guidance Documents:}

- Set forth the policy and procedures governing the participation of potentially responsible parties in the development of remedial investigations and feasibility studies under CERCLA.

\section{Scope of the Guidance Documents:}

- Discuss the following-

- Circumstances in which remedial investigations/feasibility studies may be conducted by potentially responsible parties

- Procedures for notifying potentially responsible parties when the Agency has identified target sites for the development of remedial investigations/ feasibility studies

- Principles governing potentially responsible party participation in Agencyfinanced remedial investigations/feasibility studies

\section{Technical Approach:}

- Discuss drawbacks to previous approaches to potentially responsible party participation in remedial investigations/feasibility studies.

- Discuss situations where private parties may conduct a remedial investigation or feasibility study.

- Potentially responsible parties will be subject to criteria enunciated in the final version of remedial investigation and feasibility study technical manuals. 
- Until remedial investigation and feasibility study guidances are final, potentially responsible parties may develop remedial investigations/feasibility studies if they commit to follow workplans for remedial investigations/feasibility studies prepared by Agency-supervised contractors.

- Discuss the way in which potentially responsible parties will be notified of the opportunity to perform the remedial investigation/feasibility study.

- Discuss the Regional role in remedial investigation/feasibility study development by potentially responsible parties.

\section{Comparison With Relevant Documents:}

- These documents are unique in scope.

Applicability to RCRA Corrective Measures:

- These documents address the administrative procedures governing potentially responsible party participation and are not directly relevant to the RCRA corrective measures program. 


\section{Appendix A-"A Prime" and "A" List Documents on the OSWER Hazardous Waste Bibliography Not Included in This Compendium* (Page 1 of 3)}

\section{Category}

Remedial Action

Technical Guidance: Multimedia

Site Assessment and Health Assessment
Directory of Commercial Hazardous Waste

Treatment and Recycling Facilities

Guidance Manual for Research, Development and Demonstration Permits Under 40 CFR $§ 270.65$

Practical Guide-Trial Burns for Hazardous Waste Incinerators: Project Summary

Prohibition on the Placement of Bulk Liquid Hazardous Waste in Landfills-Statutory Interpretive Guidance

Treatment Technology Briefs: Alternatives to Hazardous Waste Landfills

Design and Development of Hazardous Waste Reactivity Testing Protocol

Handbook, Remedial Action at Waste Disposal Sites, Revised

Test Methods for Evaluation of Solid Waste: Physical/Chemical Methods, 3rd Edition

Geophysical Methods for Location of Abandoned Wells

Geophysical Techniques for Sensing Buried Wastes and Waste Migration

Practical Guide for Ground-Water Sampling

RCRA Ground-Water Monitoring Technical Enforcement Guidance Document

Sediment Sampling Quality Assurance User's Guide

Soil Sampling Quality Assurance User's Guide

\section{Issuing Office Ordering Information}

EPA/OSW

EPA Report \#530/SW-87/024

Washington, DC NTIS Ref. \#PB88-109699

EPA/OSW
Washington, DC

EPA Report \#530/SW-86/008

NTIS Ref. \#PB86-229192

OSWER Directive 9527.00-1A

EPA/OSWER/

EPA Report \#600/2-86/050

HWERL

NTIS Ref. \#PB86-190246/AS

Cincinnati, $\mathrm{OH}$

EPA/OSW

EPA/530/SW-86-016

Washington, DC

NTIS Ref. \#PB86-212271

EPA/ORD/

HWERL

Cincinnati, $\mathrm{OH}$

EPA Report \#600/9-86/017 NTIS Ref. \#PB87-110680

EPA/ORD/

HWERL

EPA Report \#600/2-84/057

NTIS Ref. \#PB84-158807

Cincinnati, $\mathrm{OH}$

EPA/OSWER/ OERR/HWERL

EPA Report \#625/6-85/006 NTIS REF. \#PB87-201034

Cincinnati, $\mathrm{OH}$

OSWER Directive $9380.0-4$

EPA/OSWER

EPA Report \#SW-846

Washington, DC

GPO Ref. \#955-001-00000-1

EPA/ORD/EMSL EPA Report \#600/4-84/065 Las Vegas, NV NTIS Ref. \#PB84-212711

EPA/ORD/EMSL EPA Report \#600/7-84/064 Las Vegas, NV NTIS Ref. \#PB84-198449

EPA/OSWER/ERLEPA Report \#600/2-85/104 Ada, OK NTIS Ref. \#PB86-137304

EPA/OSW EPA Report \#530/SW-86/055

Washington, DC. NTIS Ref. \#PB87-107751

EPA/ORD/EMSL EPA Report \#600/4-85/048 Las Vegas, NV NTIS Ref. \#PB85-233542

EPA/ORD/EMSL ·EPA Report \#600/4-84/043 Las Vegas, NV NTIS Ref. \#PB84-198621 


\section{Appendix A-"A Prime" and "A" List Documents on the OSWER Hazardous Waste Bibliography Not Included in This Compendium*}

(Page 2 of 3 )

\begin{tabular}{|c|c|c|c|}
\hline Category & Document Title & Issuing Office & Ordering Information \\
\hline & $\begin{array}{l}\text { Survey of Mobile Laboratory Capabilities } \\
\text { and Configurations }\end{array}$ & $\begin{array}{l}\text { EPA/ORD/EMSL } \\
\text { Las Vegas, NV }\end{array}$ & EPA Report \#600/X-84/170 \\
\hline & $\begin{array}{l}\text { Health Effects Assessment Documents } \\
\text { (58 Chemical Profiles) }\end{array}$ & $\begin{array}{l}\text { EPA/OERR/OHEA } \\
\text { Cincinnati, OH }\end{array}$ & $\begin{array}{l}\text { AEPA Report \#540/1-86/001 } \\
\text { through } 058 \\
\text { NTIS Ref. \#PB865-134111/AS }\end{array}$ \\
\hline \multirow[t]{10}{*}{$\begin{array}{l}\text { Construction } \\
\text { Techniques/ } \\
\text { Procedures }\end{array}$} & Dust Control at Hazardous Waste Sites & $\begin{array}{l}\text { EPA/ORD/ } \\
\text { HWERL } \\
\text { Cincinnati, OH }\end{array}$ & $\begin{array}{l}\text { EPA Report \#540/2-85/003 } \\
\text { NTIS Ref. \#PB86-190105 }\end{array}$ \\
\hline & $\begin{array}{l}\text { Occupational Safety and Health: Guidance } \\
\text { Manual for Hazardous Waste Site Activities }\end{array}$ & $\begin{array}{l}\mathrm{NIOSH} \\
\text { Cincinnati, } \mathrm{OH}\end{array}$ & GPO Reference \# (NIOSH Pub.) 85-115 \\
\hline & $\begin{array}{l}\text { Protecting Health and Safety at Hazardous } \\
\text { Waste Sites: An Overview }\end{array}$ & $\begin{array}{l}\text { CERI } \\
\text { Cincinnati, OH }\end{array}$ & EPA Report \#625/9-85/006 \\
\hline & Standard Operating Safety Guides & \multicolumn{2}{|c|}{$\begin{array}{l}\text { EPA/OERR/HRSDOSWER Directive 9285.1-01B } \\
\text { Washington, DC }\end{array}$} \\
\hline & $\begin{array}{l}\text { Decontamination Techniques for Mobile } \\
\text { Response Equipment Used at Waste Sites } \\
\text { (State-of-the-Art Survey) Final Report }\end{array}$ & $\begin{array}{l}\text { EPA/ORD/ } \\
\text { HWERL } \\
\text { Cincinnati, OH }\end{array}$ & $\begin{array}{l}\text { EPA Report \#600/2-85/105 } \\
\text { NTIS Ref. \#PB85-247021/XA }\end{array}$ \\
\hline & $\begin{array}{l}\text { Emergency Response Procedures for Control } \\
\text { of Hazardous Substance Release }\end{array}$ & $\begin{array}{l}\text { EPA/ORD/ } \\
\text { HWERL } \\
\text { Edison, NJ }\end{array}$ & $\begin{array}{l}\text { EPA Report \#600/D-84/023 } \\
\text { NTIS Ref. \#PB84-128719 }\end{array}$ \\
\hline & $\begin{array}{l}\text { Guidance Manual for Minimizing Pollution } \\
\text { From Water Disposal Sites }\end{array}$ & $\begin{array}{l}\mathrm{EPA} / \mathrm{ORD} / \mathrm{WERL} \\
\text { Cincinnati, OH }\end{array}$ & $\begin{array}{l}\text { EPA Report \#600/2-78/142 } \\
\text { NTIS Ref. \#PB78-268905 }\end{array}$ \\
\hline & $\begin{array}{l}\text { Guide for Decontaminating Buildings, } \\
\text { Structures and Equipment at Superfund Sites }\end{array}$ & $\begin{array}{l}\text { EPA/ORD/ } \\
\text { HWERL } \\
\text { Cincinnati, OH }\end{array}$ & $\begin{array}{l}\text { EPA Report \#600/2-85/028 } \\
\text { NTIS Ref. \#PB85-201234/AS }\end{array}$ \\
\hline & Superfund Removal Procedures-Revision \#2 & $\begin{array}{l}\text { EPA/ERD } \\
\text { Edison, NJ }\end{array}$ & OSWER Directive $9360.0-03 \mathrm{~A}$ \\
\hline & $\begin{array}{l}\text { Technical Guidance Document: Construction } \\
\text { Quality Assurance for Hazardous Waste Land } \\
\text { Disposal Facilities (Final Report) }\end{array}$ & $\begin{array}{l}\text { EPA/ORD/ } \\
\text { HWERL } \\
\text { Cincinnati, OH }\end{array}$ & $\begin{array}{l}\text { EPA Report \#530/SW-86/031 } \\
\text { NTIS Ref. \#PB87-132825 } \\
\text { OSWER Directive } 9427.00-3\end{array}$ \\
\hline Costing Techniques & $\begin{array}{l}\text { Costs of Remedial Response Actions at } \\
\text { Uncontrolled Hazardous Waste Sites }\end{array}$ & $\begin{array}{l}\text { EPA/OSWER/ } \\
\text { WERL } \\
\text { Cincinnati, OH }\end{array}$ & $\begin{array}{l}\text { EPA Report \#600/2-82/035 } \\
\text { NTIS Ref. \#PB83-164830 }\end{array}$ \\
\hline
\end{tabular}




\section{Appendix A-"A Prime" and "A" List Documents on the OSWER Hazardous Waste Bibliography Not Included in This Compendium* (Page 3 of 3 )}

\begin{tabular}{|c|c|c|c|}
\hline Category & Document Title & Issuing Office & Ordering Information \\
\hline \multirow[t]{2}{*}{$\begin{array}{l}\text { Program Guidance } \\
\text { Documents }\end{array}$} & $\begin{array}{l}\text { CERCLA Compliance with Other } \\
\text { Environmental Statutes }\end{array}$ & $\begin{array}{l}\text { EPA/OERR } \\
\text { Washington, DC }\end{array}$ & OSWER Directive $9234.0-02$ \\
\hline & $\begin{array}{l}\text { Petitions to Delist Hazardous Wastes: } \\
\text { A Guidance Manual }\end{array}$ & $\begin{array}{l}\text { EPA/OSWER } \\
\text { Washington, DC }\end{array}$ & $\begin{array}{l}\text { EPA Report \#530/SW-85/003 } \\
\text { NTIS Ref. \#PB85-194488 }\end{array}$ \\
\hline \multirow[t]{2}{*}{ Case Studies } & $\begin{array}{l}\text { Case Studies 1-23: Remedial Responses at } \\
\text { Hazardous Waste Sites }\end{array}$ & $\begin{array}{l}\text { EPA/OSWER/ } \\
\text { WERL } \\
\text { Cincinnati, OH }\end{array}$ & $\begin{array}{l}\text { EPA Report \#540/2-84/002B } \\
\text { NTIS Ref. \#PB85-121739 }\end{array}$ \\
\hline & $\begin{array}{l}\text { Summary Report: Remedial Response at } \\
\text { Hazardous Waste Sites }\end{array}$ & $\begin{array}{l}\text { EPA/OSWER/ } \\
\text { WERL } \\
\text { Cincinnati, OH }\end{array}$ & $\begin{array}{l}\text { EPA Report \#540/2-84/002A } \\
\text { NTIS Ref. \#PB86-121721 }\end{array}$ \\
\hline
\end{tabular}

* For further information see the OSWER Hazardous Wastes Bibliography, October, 1987, EPA/540/1-87-001 (OSWER Directive 9380.1-02). 


\section{sopen Ofiroe}

J. Lawrence, CE-64

Knight, CP-20

bn Fisher, CP-40

ad Campbell, CR-141

ke Barrett, DP-6.1

imothy Pflaum, DP-9

harles Halsted, DP-27

eve Richardson, DP-60

erry Gears, DP-62

hin Ford, DP-63

itz Wolf, DP-633

ni Goodwin, DP-636

chard Hahn, DP-64

andy Lyech, DP-643

hn Marchetti, DP-644

an Rhoades, DP-65

. Mario Fiori, DR-1

hnemarie Cleary, EH-1

nne Fairobent, EH-1

iry Weiner, EH-5

e Fitzgerald, EH-30

ary Pettengill, EH-40

ck Jones, EH-41

chard Moore, EI-23.1

in Disbrow, EI-531

len Livingston-Behan, EM-1.1

ul Grimm, EM-2

bm Elsasser, EM-4

11 Bixty, EM-6

andal Scott, EM-20

1 Lytle, EM-30

eve Cowan, EM-30

in Turi, EM-33

se Stevens, EM-331

ark Frei, EM-34

y Rhoderick, EM-342

seph Coleman, EM-35

ent Hancock, EM-352

ck Baublitz, EM-40

in Fiore, EM-42

11 Wisenbaker, EM-43

1ly Mann, EM-44

ark Stahr, EM-441

lph Lightner, EM-45

yde Frank, EM-50

Iry Harmon, EM-53

mes Farley, ER-8.2

ederick Koomanoff, ER-10

bert Evans, ER-13

t Goel, ER-14

avid Goodwin, ER-20.1

mer Goktepe, ER-22

seph MaGrory, ER-23

intoinette Joseph, ER-40

hn Yates, ER-42

even Rossi, ER-53

illiam Osburn, ER-73

obert Wood, ER-74

mes Carney, ER-92

enise Swink, FE-4

lark Matarrese, FE-64

avid Jewett, FE-222

al Delaplane, FE-421

filliam Dennison, GC-11

harles Bradley, NE-33

aj Sharma, NE-47

obert Gisch, NE-60

enry Garson, NP-1

ichard Englehart, NP-2

harles Ebbecke, NP-20

itty Gandee, NP-50

eter Ritzcovan, NP-52

avid Hoel, NP-53

eve Frank, NP-54

avid Moses, PE-70

ranklin Pelers, RW-2

eve Brocoum, RW-22
Dwight Shelor, RW-30

Gerald Parker, RW-333

Rick Bradley, S-1

Rodney Adelman, WDC

\section{Field Ofinces}

N. S. Dienes, Albuquerque Field Office Dennis Krenz, Albuquerque Field Office Rich Sena, Albuquerque Field Office C. L. Soden, Albuquerque Field Office Mike Butler, Brookhaven Area Office

DJ. Cook, Central Training Academy, AL

Joel Haugen, Chicago Field Office

J. Hunze, Chicago Field Office

Barrett Fritz, Chicago Field Office

John Kennedy, Chicago Field Office

Jerry Lyle, Idaho Field Office

Gerald C Bowman, Idaho Field Office

Walt Sato, Idaho Field Office

Robert Rothman, Idaho Field Office

Bruce Church, Nevada Field Office

Don Elle, Nevada Field Office

Joe Fiore, Nevada Field Office

Steve Mellington, Nevada Field Office

J. D. Ross, Nevada Field Office

Rodney R. Nelson, Oak Ridge Field Office

H. Wayne Hibbitts, Oak Ridge Field Office

Robert Sleeman, Oak Ridge Field Office

Peter Gross, Oak Ridge Field Office

Larry Radcliff, Oak Ridge Field Office

Robert E. Tiller, Fernald Field Office

G. Westerbeck, Fernald Field Office

R.D. Izatt, Richland Field Office

Bob Holt, Richland Field Office

Leo Little, Richland Field Office

Frazer Lockhart, Rocky Flats Office

Tom Lukow, Rocky Flats Office

Terry Vaeth, Rocky Flats Office

Mark Van Derpuy, Rocky Flats Office

J. Cullen, San Francisco Field Office

Jim Davis, San Francisco Field Office

Joe Juetten, San Francisco Field Office

Ed Ballard, San Francisco Field Office

James Hartman, San Francisco Field Office

Thomas Heenan, Savannah River Field Office

Lou Goidell, Savannah River Field Office

Leonard Sjostrum, Savannah River Field Office

A. B. Gould, Savannah River Field Office

T. J. Rowland, West Valley Project Office

Rob Waldman, Alaska Power Administration

Alex Crawiey, Bartlesville Project Office

Thomas Wesson, Bartlesville Project Office

Alexandra Smith, Bonneville Power Administration, AJ Thru: BPA, RM 80033

John Ganz, Morgantown Energy Technology Center

Joseph Martin, Morgantown Energy Technology

Center

Jim Killen, Naval Petroleum Reserves in Califomia

David Miles, Naval Petroleum Reserves in Wyoming, Utah, \& Colorado, Casper, WY

Melvin Keller, Pittsburgh Energy Technology Center

Earl Shollenberger, Pittsburgh Naval Reactors Office, Thru: NE-60

Andrew Seepo, Schenectady Naval Reactors Office, Thru: NE-60

Jim Lloyd, Southeastern Power Administration

Don Hayes, Southwestern Power Administration

Melissa Smith, Strategic Petroleum Reserve

Project Management Office

Warren Jamison, Western Power Administration
Prince Ramey, Manager, Amarillo Area Office (AAO)

James Morley, Manager, Dayton Area Office (DAO)

Earl Bean, Manager, Kansas City Area Office (KCAO)

Kathleen Carlson, Manager, Kirtland Area Office (KAO)

Jerry Bellows, Acting Manager, Los Alamos Area Office (LAAO)

Geraid Johnson, Manager, Pinellas Area Office (PAO)

Arlen Hunt, Waste Isolation Pilot Plant Project Office (WIPP-AL)

James Mewhinney, WIPP Project Office (WIPP-AL)

A. R. Chernoff, Jr., Project Manager, Uranium Mill Tailings

Remedial Action Project Office

Kathleen Grassmeir, Yucca Mountain Project Office

W.R. Miller, Special Projects Manager, ES\&H Division, Morgantown, WV

Paul K. Kearns, Manager, NREL

Jeff Baker, NREL Area Office

Nat Brown, SSCPO

\section{cc: Other Organizations}

National Low-Level Waste Management Program, EG\&G Idah Hazardous Waste Remedial Action Program, (HAZWRAP)

Remedial Action Program Information Center 